Article

\title{
Opportunities and Barriers for FinTech in SAARC and ASEAN Countries
}

\author{
Tasadduq Imam $^{1}(\mathbb{D})$, Angelique McInnes ${ }^{2}(\mathbb{D})$, Sisira Colombage ${ }^{3, * \mathbb{D}}$ and Robert Grose ${ }^{1}$ \\ 1 School of Business \& Law, CQUniversity (Melbourne Campus), Melbourne, VIC 3000, Australia; \\ t.imam@cqu.edu.au (T.I.); r.grose@cqu.edu.au (R.G.) \\ 2 School of Business \& Law, CQUniversity (Brisbane Campus), Brisbane, QLD 4000, Australia; \\ a.mcinnes@cqu.edu.au \\ 3 Federation Business School, Federation University, Berwick, VIC 3806, Australia \\ * Correspondence: sisira.colombage@federation.edu.au
}

check for

updates

Citation: Imam, Tasadduq

Angelique McInnes, Sisira

Colombage, and Robert Grose. 2022.

Opportunities and Barriers for

FinTech in SAARC and ASEAN

Countries. Journal of Risk and

Financial Management 15: 77.

https://doi.org/10.3390/

jrfm15020077

Academic Editor: Thanasis Stengos

Received: 25 October 2021

Accepted: 20 January 2022

Published: 13 February 2022

Publisher's Note: MDPI stays neutral with regard to jurisdictional claims in published maps and institutional affiliations.

Copyright: (c) 2022 by the authors. Licensee MDPI, Basel, Switzerland. This article is an open access article distributed under the terms and conditions of the Creative Commons Attribution (CC BY) license (https:/ / creativecommons.org/licenses/by/ $4.0 /)$.

\begin{abstract}
This article assesses the opportunities and challenges for different categories of FinTechs in the SAARC and ASEAN regions. We consider the global financial inclusion data released by the World Bank and map the responses to gain insights into the opportunities and challenges for FinTechs in the respective regions. We develop a new index, termed the FinTech Opportunity Index (FOI), to conceptualise the opportunities and barriers based on individual savings, borrowings, purchasing behaviour, and payment preferences. We note that FinTech services have potential opportunities for expansion in the ASEAN regions but less so in the SAARC regions. The need for different types of FinTech services varies between regions. Services such as crowdfunding, neobanks, and InsurTech have potential in the ASEAN regions, especially with the positive attitude towards entrepreneurship and asset investments. In the SAARC regions, InsurTechs linked to health care has potential along with LendTechs and neobanks. We further note that males, and the young are more likely adopters of FinTechs in both regions. The analysis suggests the need for innovative promotions and education to motivate the more sceptical, especially women and the elderly population, to adopt FinTech services.
\end{abstract}

Keywords: FinTech; SAARC; ASEAN; technology adoption

\section{Introduction}

FinTechs (financial technologies) have expanded the financial services digital ecosystem across countries, particularly during the COVID-19 crisis (Abdillah 2020; Rahman et al. 2018). However, FinTech adoption in different developing countries has been slow, despite them having different opportunities for growth and expansion of the digital economy, as is vital for future economic sustainable growth (Iman 2018; Zhang et al. 2020).

In this research, we consider two regions with similar economic, political, and social structures-the SAARC (South Asian Association for Regional Cooperation) region and the ASEAN (Association of South East Asian Nations) region (Rahman et al. 2018). The South Asian Association of Regional Cooperation (SAARC) region, currently comprises eight countries (India, Pakistan, Bangladesh, Sri Lanka, Nepal, Bhutan and the Maldives, and Afghanistan) and came into effect in 1985 with a view to encourage socio-cultural development and interregional cooperation and collaborations (South Asian Association for Regional Cooperation 2020). The total population of SAARC countries approximates the total population of China, South Korea, and Japan (Dey et al. 2019). Although most SAARC countries have a strong historical connection with the late British/Indian Empire, South East Asian countries have a high diversity in ethnicity, religion, and language (Dey et al. 2019) and have a median age of 27 (Prasad and Aravindakshan 2021). The political and social systems of these countries have incorporated "the English language, standard English spelling, Westminster-style Parliamentary democracy, the common law legal system, driving on the left, etc." (Dey et al. 2019, p. 1020). The region hosts a culture 
that is strongly familial and collectivist in ethos and practices, and exists under an economic context that is highly reliant on banking systems, and where digital services are evolving (Dey et al. 2019; Pandey et al. 2019; Prasad and Aravindakshan 2021). The Association of South East Asian Nations (ASEAN), represents 10 countries (Brunei, Cambodia, Indonesia, Lao PDR (or Laos), Malaysia, Myanmar, Philippines, Singapore, Thailand, and Vietnam), and was established in 1967 (Association of South East Asian Nations 2020). The region is the seventh largest economy in the world with a combined GDP of \$US2.5 trillion, and is expected to be the fourth largest economy by 2030 (Aujirapongpan et al. 2020). The region hosts an economic context that encourages digitisation (Avirutha 2021) and has a focus on developing communities respecting equity, freedom, and a collective spirit (Ullah and Ming Yit Ho 2021).

In 2016 ASEAN and SAARC countries comprised $8.8 \%$ and $23.75 \%$ respectively of the world's population and contributed a combined $5.81 \%$ to the world's GDP (Rahman et al. 2018). Economic conditions in ASEAN and SAARC countries are quite distinct, with GDP per capita in ASEAN countries considerably higher than SAARC countries (Akhter 2019), and income convergence among member countries being more evident in the ASEAN regions than in the SAARC regions (Zia and Mahmood 2019). Compared to OECD (Organization for Economic Cooperation and Development) countries, which generally have a larger aging population, the SAARC and ASEAN regions have a larger younger population (Rahman et al. 2018). Their contributions to the world economy cannot be ignored.

Thus, it is interesting to explore the extent that FinTech services, including those offered by traditional banks, can develop in these regions, and potentially contribute towards reducing the financial inclusion gap. Today, smartphone devices and their applications have become an integral part of people's daily lives, particularly in the SAARC and ASEAN regions, where the underlying context and social media have led to the high growth of smartphone adoptions (Babu 2016; Dey et al. 2019; Prasad and Aravindakshan 2021; Widyastuti 2017). Different categories of FinTechs have the opportunity to benefit these regions, especially by making financial services accessible to rural and remote populations where banking services are not available (GSMA 2019; Gupta and Xia 2018; Jain and Gabor 2020; Mohammad 2020; Patil et al. 2018; Schatt 2014). Indeed, in SAARC countries, given the deficiencies in financial infrastructure, the opportunities of expanding mobile banking services has expanded to those who cannot access traditional banking facilities (Lenka and Barik 2018). In the ASEAN regions, digital financial services also hold potential to stimulate economic growth, banking and financial stability (Banna and Alam 2021). Furthermore, FinTech services are not all the same. Different FinTech services bring different benefits to a user, and the available services will not necessarily appeal to everyone in each of these regions. Thus, an insight into the potential of different FinTech services in the area could be of interest to FinTech providers, especially from a business development and expansion perspective. To the best of our knowledge, such an exploration that comprehensively covers the SAARC and ASEAN regions is missing. There is, furthermore, a lack of literature that compares FinTech opportunities and barriers in the SAARC and ASEAN regions. This research article fills these gaps.

In this respect, it is worth referring to the Global Findex Database (GFD), which periodically stores different financial inclusion information, such as mobile phone and internet usage for financial transactions. While there are academic articles (Demirguc-Kunt et al. 2018; GSMA 2019; OECD 2020) that incorporate the GFD to help explore the financial inclusion gaps and determinants across regions, there is a deficiency in the literature exploring the dataset from the perspective of FinTech opportunities and barriers, especially with regards to the potential use of mobile financial services and the financial inclusion barriers in the surveyed countries. There are articles that have reviewed the mobile payment literature (Dahlberg et al. 2008, 2015) and the factors that influence their acceptance (Schierz et al. 2010) and assumed risks (Yang et al. 2015). Other articles have examined the way FinTech adoption can influence consumers' use of credits (Carlin et al. 2017), examine 
the perceived risks and benefits that influence FinTech adoptions at different stages (Ryu 2018), and examine the determinants influencing FinTech usage (Singh et al. 2020). Many existing articles have principally focused on specific regions with small-sized samples, and drawn conclusions on Fintech adoption based on theoretical models such as the technology acceptance model (TAM) (Davis 1993; Davis et al. 1989). To the best of our knowledge, however, there is no research that focuses on individuals' buying, savings, and borrowing behaviour, and use of financial services as captured by the GFD. Nor does any research maps this behaviour and usage to conceptualise the opportunities and barriers for FinTech services. This article bridges this gap.

The following research questions (RQs) are addressed:

- What are the opportunities and barriers for different FinTech services in the SAARC and ASEAN regions?

- Is there any notable difference between the SAARC and ASEAN regions concerning digital financial services adoption and potential developments? In addressing these RQs, we make the following contributions:

- The GFD has typically been assessed to conceptualise banking and financial inclusion gaps, and opportunities for digital payment services (Demirguc-Kunt et al. 2018). We go beyond this practice and conceptualise the GFD information to assess opportunities and barriers to FinTech developments across countries for payment services and other different categories of FinTech services.

- We compare the relative opportunities and barriers of FinTechs across the SAARC and ASEAN regions. To the best of our knowledge, this is pioneering work.

- We propose a new index, named the FinTech Opportunity Index (FOI), to conceptualise the opportunities and barriers across the SAARC and ASEAN regions, based on individuals' savings, borrowing, purchasing behaviour, and payment preferences. It is anticipated that this new index will guide further research in this space.

- We explore the association between the demographic attributes of the two regions and opportunities for FinTech development-another area where the literature has remained largely silent.

Overall, we make an academic contribution that can guide further similar research across locations. Simultaneously, we make a practical contribution. The outcomes of this research will be particularly useful to FinTech providers and economic policy makers, especially in the current context, where social distancing and public health protection have become the new norm, leading to an increasing acceptance of digital systems for shopping, payments, and financial services.

\section{Literature Review}

Although providing financial services via technology is not a new concept, attention towards FinTechs from a broad group of stakeholders has been quite recent (Arner et al. 2016), Thus, research in this space is still at a very early stage and is gradually evolving. So, too, is the development and expansion of FinTechs in both developed and developing countries (Arner et al. 2016; Patil et al. 2018). To clarify the position of the article, this literature review will focus on the evolution and characteristics of different digital financial services, FinTech adoptions, barriers, and opportunities for adoption in the context of the ASEAN and SAARC regions.

\subsection{Different Types of FinTech}

FinTech is an umbrella term that covers different financial services offered as technological solutions via the internet and/or via mobile apps, and its historical evolution can be traced to the early 1990s (Arner et al. 2016). There are several categories of Fintech services that can enhance the financial service experience of consumers by digitising financing, investment, money, insurances, and financial advice (Chinnasamy et al. 2021; Gomber et al. 2017; Pollari and Teper 2021). Some of the common FinTech services include: 
- PayTech-(payment technologies) offering digital payment services;

- LendTech-(lending technologies) offering streamlined accurate digital lending solutions;

- Crowdfunding/equity financing - offering opportunities to raise funds through the sale of securities online or via some incentive promises to the funders;

- Neobanks-offering digital financial and banking services;

- RegTech (regulatory technologies)—offering the delivery of regulatory compliance securely and cost-effectively within a standardised, integrated, transparent ecosystem;

- InsurTech (insurance technologies)—offering insurance solutions within a digital financial ecosystem; and

- Personal finance/robo-advisers/WealthTech—offering personal digital financial planning or management services using robotic technology involved in portfolio construction and stock trading.

Mobile payment services (a form of PayTech) facilitate payments for purchases or bills using mobile devices such as smartphones, tablets, or other computing and mobile technologies (Dahlberg et al. 2008; de Luna et al. 2019). The services have expanded across regions, including developing countries with an increased usage of mobile devices and supportive socioeconomic conditions and other determinants facilitating such growth (Iman 2018; Kang 2018). Peer-to-peer payments, and mobile payment services have expanded to cover government payments to individuals (Iman 2018).

LendTech and crowdfunding have evolved, especially as alternatives to traditional financing sources such as banks, venture capitalists, angel investors, and government fundings (Gomber et al. 2017). LendTech can provide borrowing solutions to consumers with weak credit ratings or consumers who may be refused mortgage loans by traditional credit entities (Jagtiani et al. 2021). The use of technology has benefited credit entities by allowing assessments of extended information and prediction of default risks (Jagtiani and Lemieux 2019).

Crowdfunding platforms facilitate entrepreneurial financing and business ventures, and, contrary to traditional sources, connect entrepreneurs and investors from diverse geographical locations (Agrawal et al. 2011; Mollick 2014). There are many different crowdfunding models (Meyskens and Bird 2015). Of these the most common is the equity crowdfunding model, which can make entrepreneurial investment opportunities available to inexperienced investors and where investors expect compensation from the ventures' cash inflows (Hornuf and Schwienbacher 2018; Ralcheva and Roosenboom 2016).

Neobanks provide banking functions fully online, and are gaining popularity among millennials and consumers expecting enhanced banking experiences (El-Gohary et al. 2021; Temelkov 2020). They often operate at a low cost, offering consumers banking services at a low fee and investors a higher return (Maiti et al. 2021).

In a context of high-volume information, changing regulations, and the need for protection of consumers' rights, RegTechs assist businesses with regulatory compliance, controlling risks, and reporting (Butler and O'Brien 2019). With the development of different FinTech services, RegTechs are expected to play a significant role in monitoring information and the prevention of financial crimes (Dubey et al. 2020).

InsurTech is another recent FinTech development, that automates data collection, helps manage risks, and offers digital and integrated insurance solutions (Stoeckli et al. 2018). With significant investments in the InsurTech industry, it is expected that InsurTechs will increasingly disrupt traditional insurance providers in the aftermath of COVID-19 (Neale et al. 2020).

Personal financial management services and WealthTech have seen a spike in growth recently, especially with the increased digitisation of financial markets and technological advancements facilitating functions such as automated trading, micro-investments at a low commission, automated asset management, and retail investments (Dziawgo 2021). WealthTechs can make available wealth management opportunities which were traditionally accessible only to high-worth individuals and middle-class cohorts (Arslanian 2018; Li et al. 2020). 
Thus, recent developments in the information technologies space, including machine learning, big data analytics, cloud computing, blockchain, distributed database systems, and virtualisations have paved the way to a variety of FinTechs that target financial services.

\subsection{FinTechs in SAARC and ASEAN Country Context}

It is informative to note the differences in the adoption and development of FinTechs in SAARC and ASEAN regions.

\subsubsection{SAARC Countries}

India is the leading country among the SAARC nations in adopting digital technologies. The Indian government is digitising services and educating citizens under the "Digital India" outreach programme. India has also introduced polices that demonetise currency notes (Government of India, Ministry of Electronics \& Information Technology n.d.; Kumar and Puttanna 2018). Currently, India is facing a difficult regulatory and operating environment and a slowing of growth in the adoption of mobile money, compared to the ASEAN region (GSMA 2019). Additional challenges for FinTech development in India include the preference towards cash transactions, fraudulent online activities, and the lack of sufficient support and incentives (Priya and Kanagala 2019).

Pakistan is another SAARC country where FinTech services are growing, even though very few FinTech firms operate outside the major cities (Ali et al. 2021; Saleem 2021). With a young, technology-savvy population and high smartphone usage, Pakistan has all the attributes that are conducive to FinTech adoption (Saleem 2021). However, perceptions associated with risk and the lack of partnerships between local firms and FinTech companies are seen as barriers for the rapid development of FinTech services in Pakistan (Ali et al. 2021; Saleem 2021).

In Bangladesh, the government has an explicit focus on digitalisation, including supporting FinTech initiatives (Ayoungman et al. 2021). While different FinTech services, especially mobile banking, have expanded in Bangladesh, there are FinTech categories such as crowdfunding, cryptocurrency, and InsurTech that have a limited penetration or are not allowed by law (Ayoungman et al. 2021). Users' perceived risks and trust are noted as critical determinants of FinTech adoption (Hasan 2021). Issues associated with data storage, and insufficient development of human resources remain as barriers in FinTech development (Rahman et al. 2021).

In Nepal, the growth in mobile banking is strong, especially among the young who are aware of technological developments and are willing to accept mobile banking services and the benefits they bring (Kunwar and Thakur 2019). Indeed, several payment companies have received approval to operate in Nepal and have been adopted by the Nepalese population for bill and invoice payments (Bazarbash 2020).

FinTechs, especially peer-to-peer lending and cryptocurrency, have achieved considerable success in Sri Lanka, but uncertainties and risks associated with this form of innovation remain (Dharmadasa 2021). Additionally, regulatory barriers and the lack of a central structure for identity verification have hindered FinTechs' progression in Sri Lanka (Samarasinghe 2021).

Research on the prospects of mobile money in Afghanistan have noted mixed views concerning acceptance (Blumenstock et al. 2015). There are further concerns about internet costs and available infrastructure, which have the potential to hinder the adoption of sophisticated technologies (Lukonga 2021).

Bhutan has strategies encouraging FinTech developments (FIS of Royal Monetary Authority of Bhutan 2020), and has recently adopted an innovative Indian FinTech payment service that is expected to benefit both its citizens and tourists (Vidyashree 2021).

Research on internet banking in the Maldives reflects the influence that trust, social context, and performance expectations can have on its adoption (Zahir and Gharleghi 2014), and there is a view that offering Islamic FinTech services holds promise in the country (Alam and Zameni 2021). 
Overall, FinTech initiatives involving SAARC countries have generally focused on mobile money and payment services, but there also remain opportunities for other services such as crowdfunding, which have made limited penetration in the SAARC region (Nepali 2021).

\subsubsection{ASEAN Countries}

In the ASEAN region, there are concerns about low financial and digital literacy rates in the Philippines, Indonesia, and Thailand (Banna and Alam 2021). Even so, FinTech services have emerged in each of the countries across the ASEAN region.

Mobile phones have led to mobile payment apps in Indonesia, such as TCASH (Iman 2018) and "Go-Pay" via the Gojek start-up application (Abdillah 2020, p. 265). Focusing on the user experience of Indonesian computer science students belonging to the Millennial and Z generations, Abdillah (2020) claims that despite its efficiency and clarity, the Go-Pay service needs to develop a unique footprint. Research also points to user trust, rather than perceived risks, as a key factor influencing FinTech adoption in Indonesia (Meyliana et al. 2019). There are calls for establishing laws regulating the fast-growing FinTech services in Indonesia (Kharisma 2020). Research additionally points to the potential for FinTech services to assist micro, small, and medium-sized businesses to expand and develop (Darma et al. 2020).

Malaysia has seen the growth of Islamic FinTech organisations, including those providing crowdfunding and data analytics services (Hasan et al. 2020). Research suggests that Islamic FinTech services have the potential for further development in Malaysia, and there are calls to establish regulations to govern the services on offer (Ab et al. 2020; Miskam et al. 2019). Research also notes that Malaysian males have a greater intention to adopt FinTech services than females (Tun-Pin et al. 2019).

Singapore is a leader in the ASEAN region with respect to hosting FinTech services, and attracting funding for relevant initiatives (Lin 2019). Singapore is regarded as "a regional financial capital" (Lin 2019) with a financial ecosystem and policies conducive to FinTech services (Tao and Azhgaliyeva 2018). A particularly unique initiative in Singapore is a well-established regulatory sandbox that facilitates experimentation in Fintech products, while also considering public perceptions, stereotypes and protection of consumer rights (Fan 2018; Lin 2019; Ng 2018). Indeed, the impact of such a regulatory sandbox is evident in research. A study comparing peer-to-peer lending services in Singapore and Indonesia notes that while FinTech start-ups enjoy a very supportive context in Singapore from a broad range of consumers, the development of such services in Indonesia is affected by conflicting regulations, and the user base is made up of Millennials (Yunus 2019).

FinTech is gradually developing in the Philippines, although relatively low financial literacy and difficulties in accessing funds and expertise have acted as barriers to such development (Schellhase and Garcia 2019). Research, however, suggests that FinTechs can act as complementary service and be beneficial to incumbent formal financial institutions (Low and Wong 2021).

FinTech payment services are expanding rapidly in Thailand and the expansion has been energised by public-private entity partnerships (Moenjak et al. 2020). The country hosts a central platform for the verification of individual identity, and this platform is likely to facilitate the further expansion of different FinTech services (Moenjak et al. 2020). Research has also explored the acceptability of artificial intelligence (AI)-based financial services in Thailand (Noonpakdee 2020).

In Myanmar, users' perception of credibility and compatibility appear to drive the adoption of FinTech lending services, while perceptions about costs have a negative influence (Aye 2021). Myanmar has recently introduced several reforms in the financial services sector, including those giving permission to foreign banks to operate FinTech services. It is worth noting that a number of microfinance and nonbank financial institutions have emerged in Myanmar in recent times (Aye 2021). An interesting aspect in Myanmar is what Laik and Wei (2019) refer to as the "leapfrog nature" of its society. While mobile phone penetration in the country was low just a few years ago, the penetration of mobile 
and smartphones in recent years has been very significant-an indication of the growth potential for mobile banking services in the country (Laik and Wei 2019).

There has been sound growth of FinTech organisations in Vietnam as well; however, the services covered are limited mainly to payments and associated services, with a few firms facilitating robo-advice (Morgan and Trinh 2020). There are also a number of foreign owned FinTech services in the country (Tapanainen 2020). Research suggests that there is potential for the development of microfinancing via FinTechs in Vietnam (Dang and Vu 2020).

FinTech services are in the very early stages of development in Lao PDR, with deposit services dominating and a few mobile add-on services facilitating card payments. (Morgan and Long 2019). Inadequate access to the internet and low financial literacy are noted as the main barriers to FinTech adoption (Morgan and Long 2019).

FinTechs, particularly payment services, are growing in Cambodia due to high smartphone usage, especially among the Millennial generation, which seeks efficient and convenient financial transactions (Cheng et al. 2018). Interestingly, social influence may not be effective in convincing the Cambodian Millennials to adopt FinTechs (Cheng et al. 2018).

Research suggests that Islamic financial institutions can assist the unbanked or underbanked people of Brunei Darussalam to adopt FinTech services (Ali et al. 2019). It is claimed that FinTechs can assist Brunei to fulfil its development pursuits (Haqqi 2020). However, the lack of proper regulation governing FinTech services pose risks to its expansion and there is a call for innovation in the authentication space (Haqqi 2020). Another study explored the potential of biometric authentication in Brunei and suggests that ease of use and trust are two notable factors that can impact innovation acceptance (Sulaiman and Almunawar 2021).

Overall, ASEAN countries and their road to FinTech adoption have featured in the literature at various levels. It appears that payment services have received acceptance in most ASEAN countries. The regulatory context however differs, with some countries yet to establish any meaningful regulation while other countries already have a supportive regulatory and policy regime in place.

\subsection{Drivers and Barriers for FinTechs}

The literature notes different drivers and barriers for FinTechs across countries. A particular driver in SAARC and ASEAN regions is the encouragement from national governments, who are attempting to foster an ecosystem of cyberspace, mobile phones and blockchain to empower individuals to gain access to technologies that enable them to transact from anywhere. For example, in Indonesia, the adoption of FinTech has been high among women, the Y generation, and high-school equivalents. In India, demonetisation policies have encouraged the acceptance of digital platforms (Abdillah 2020; Banna and Alam 2021; Demirguc-Kunt et al. 2018; Huwaydi and Persada 2018; Prasad and Aravindakshan 2021).

Drivers for FinTech services can also include the perceived benefits of these services by their users or the potential positive implications of their use. The literature, in this regard, points to consumer benefits associated with the use of FinTech, including making financial transactions affordable, transparent, accessible, inclusive, convenient and secure (Abdillah 2020; Patil et al. 2018; Puschmann 2017; Zhang et al. 2020). There are also explorations related to the benefits of FinTech for small and medium-sized enterprises (SMEs). Research, for instance, notes that FinTechs can play a positive role in enhancing exports (Ragimun and Yosepha 2018). It is also argued that the low costs associated with FinTech payment services to consumers can boost their spending, which in turn can enhance the growth of businesses (Agarwal et al. 2020). Fintech platforms can help reduce the cost of borrowing by assisting financial institution to be more efficient (Mardiana and Kembauw 2021). The broader implications of FinTechs are also noted and can act as drivers of these services at a national level. FinTech development can enhance job creation, entrepreneurship opportunities, and reduce the digital divide (Zhang et al. 2020). Under COVID-19-like situations, there is also 
the added advantage of avoiding the threat to health and life, because contactless payments facilitate transactions without physical contact (Srivastava et al. 2021).

Conversely, the literature also identifies various barriers to FinTech developments. The access to financial services remains a challenge in the developing economies of the world (Demirguc-Kunt et al. 2018; Mohammad 2020). Growth in FinTech in the Asia Pacific region is made all the more difficult (Aujirapongpan et al. 2020; Patil et al. 2018) because of:

- $\quad$ slower IT spending by the traditional banks; and

- concerns about security, privacy, and risks.

Other FinTech adoption challenges include regulatory barriers, a less-sophisticated population, information asymmetries, and constraints placed on FinTech companies (Arner et al. 2016; Dhar and Stein 2017; Moradi et al. 2020; OECD 2020). Consumer expectations concerning performance, perceived benefits, usefulness, usability, and associated risks can influence a person's intention to adopt FinTech services (Patil et al. 2017). Mohammad (2020) reported that social norms can have a more significant influence on the adoption of FinTech applications than perceived technology risks. However, trust mediates the relationship between perceived risks and FinTech application adoption (Mohammad 2020). Security breaches can lead to mistrust about mobile apps and detrimentally affect the intention to use FinTech services (Kang 2018). Developing confidence in new FinTech services takes time. The respective regulatory environment, such as government-initiated measures concerning cryptocurrencies in some countries, can potentially impact the cost of adoption and early adoptions (Luther 2016).

Overall, there are adoption opportunities and barriers for FinTechs across different regions. Thus, it is interesting to note the extent various contextual circumstances affect the potential of FinTech developments in the different SAARC and ASEAN countries and how the regions compare in this regard.

\subsection{Research Gaps and the Position of This Article}

Despite a rich level of literature covering both SAARC and ASEAN countries, research gaps exist. Most of the existing research has focused on a limited number of participants to draw conclusions. The GFD information (Demirguc-Kunt et al. 2018) we use in this research uses a large number of participants across the two regions. The GFD includes multiple questions covering various aspects of borrowing, savings behaviour, digital payment usage, and financial inclusion. Such information can, in turn, point to opportunities to develop FinTechs services in these two regions. To the best of the authors' knowledge, the literature is yet to explore the GFD from this angle and therefore this article has a very different perspective to the existing literature concerning FinTech adoption in SAARC and ASEAN countries.

Also, there is a limited focus on quantifying the opportunities (and barriers) faced by FinTech organisations in SAARC and ASEAN countries. Interestingly, Huong et al. (Huong et al. 2021) recently developed an index, named the "FinTech adoption index for ASEAN countries (AFAI)", which considered various indicators such as the transaction values of mobile payments, crowdfunding, crowdlending, e-commerce, marketplace lending, electronic remittance, and other macrolevel information in the ASEAN region. It is noteworthy that the AFAI (Huong et al. 2021) looked only at ASEAN countries and considered consumers' adoption of FinTech services at a macro-level, though did not explicitly score opportunities for FinTech expansion. The current article fills the above-mentioned gap by developing a new index, termed the "FinTech Opportunity Index" (FOI), to conceptualise the opportunities and barriers based on individual savings, borrowings, purchasing behaviour, and payment preferences. It is a unique index that scores potential barriers to FinTech expansion opportunities in both the ASEAN and SAARC regions. In effect, it is an index that focuses on micro-level information, such as individualistic savings and borrowing behaviour, and quantifies opportunities for the expansion of FinTechs in both the SAARC and ASEAN regions. To the best of the authors' knowledge, an index at this level of sophistication has not been developed. Also, while macro-level information, as 
considered in the AFAI, can provide useful information, micro-level information arguably provides additional insights. The current article bridges this research gap vacuum.

\section{Methodology}

For this research, we focus on a selection of questions from the 2017 GFD questionnaire as listed in Table 1 to help understand and reflect on the opportunities for FinTech development in SAARC and ASEAN countries. It is important to acknowledge that the World Bank report on the 2017 GFD mentions opportunities for digital banking and financial services in different countries (Demirguc-Kunt et al. 2018). The report, however, does not cover SAARC and ASEAN countries specifically and does not focus on a comparison of the opportunities relative to the respective economic context. Additionally, we conceptualise the opportunities across various types of FinTech technologies, not just banking and payment services. With that in consideration, we list in Table 1 our conceptualisation of the questions as barriers and opportunities relating to the different categories of FinTech. We follow a recent KPMG report (Pollari and Teper 2021) and categorise the potential FinTech services into seven groups: neobanks, lending services, personal financial (management) services, payment services, crowdfunding, RegTech (regulatory technologies), and InsurTech (insurance technologies).

Table 1. Questions and items conceptualised in this research to reflect opportunities and barriers for FinTech.

\begin{tabular}{|c|c|c|}
\hline $\begin{array}{l}\text { Item in the GFD } 2017 \text { Questionnaire (World } \\
\text { Bank 2018a) }\end{array}$ & Relevant FinTech Technologies & Explanation \\
\hline $\begin{array}{l}\text { Has the participant used a mobile phone or the } \\
\text { internet for payment, purchase, or money } \\
\text { transfer from a bank or a formal institution in } \\
\text { the prior year (i.e., prior } 12 \text { months?) }\end{array}$ & $\begin{array}{l}\text { Payment services } \\
\text { Associated services }\end{array}$ & $\begin{array}{l}\text { The response to this question captures the use } \\
\text { of digital payment, which conceptualises both } \\
\text { opportunities for and barriers to payment } \\
\text { services. Furthermore, using such services can } \\
\text { lead to opportunities for associated services } \\
\text { such as e-commerce platforms and digitisation } \\
\text { of traditional businesses. }\end{array}$ \\
\hline
\end{tabular}

What is the reason that the participant does not have a bank or a formal financial institution account?

The options are:

- $\quad$ the institutions are very far away

- the participant feels that financial services are very expensive

- $\quad$ the participant lacks the documentations needed

the participant mistrusts the institutions

there are religious causes

the participant has insufficient funds

duplication in the sense that another

family member already holds an account

the participant feels that such financial

services are not needed

Has the participant saved any money for initiating, running, or growing a business in the prior year?
Crowdfunding

RegTech

InsurTech

Neobanks
Many FinTech services have emerged to address the barriers in the question, such as financial institutions being far away or transactions being expensive. Thus, the barriers provide opportunities for all types of FinTech, while also indicating challenges to the services' expansion.
Has the participant saved any money for old age in the prior year?
Personal financial services Neobanks
Saving for starting or operating a business corresponds to entrepreneurship and business management behaviour, and which in turn corresponds to opportunities for FinTech facilitating business fundraising, insurance, and regulatory compliances.

Saving for old age reflects wealth and personal financial management behaviour, corresponding to opportunities for related FinTech services. 
Table 1. Cont.

\begin{tabular}{|c|c|c|}
\hline $\begin{array}{l}\text { Item in the GFD } 2017 \text { Questionnaire (World } \\
\text { Bank 2018a) }\end{array}$ & Relevant FinTech Technologies & Explanation \\
\hline $\begin{array}{l}\text { Did the participant save any money in the } \\
\text { prior year using: } \\
\text { - } \quad \text { a formal financial institution or bank } \\
\text { account? } \\
\text { - an informal saving entity or an } \\
\text { individual not in the family? }\end{array}$ & $\begin{array}{l}\text { Personal financial services } \\
\text { Crowdfunding } \\
\text { Neobanks }\end{array}$ & $\begin{array}{l}\text { These items correspond to actual savings } \\
\text { behaviour and in turn reflect the opportunities } \\
\text { for FinTech, and barriers thereof, especially if } \\
\text { individuals are not accustomed to using } \\
\text { banking services for saving. }\end{array}$ \\
\hline $\begin{array}{l}\text { Has the participant singly or jointly borrowed } \\
\text { any money from formal financial institutions } \\
\text { for purchasing property or land in the } \\
\text { prior year? }\end{array}$ & $\begin{array}{l}\text { Lending services } \\
\text { Personal financial services } \\
\text { Neobanks }\end{array}$ & $\begin{array}{l}\text { This item relates to the participant's attitude } \\
\text { towards borrowing for purchasing assets, and } \\
\text { thus corresponds to the opportunities for } \\
\text { lending services and relevant FinTech. }\end{array}$ \\
\hline $\begin{array}{l}\text { Has the participant borrowed, singly or jointly, } \\
\text { any money from formal financial institutions } \\
\text { for medical or health reasons in the prior year? }\end{array}$ & $\begin{array}{l}\text { Lending services } \\
\text { Personal financial services } \\
\text { InsurTech } \\
\text { Neobanks }\end{array}$ & $\begin{array}{l}\text { This item relates to the participant's attitude } \\
\text { towards borrowing for medical purposes, and } \\
\text { thus corresponds to the opportunities for } \\
\text { lending and health insurance services and } \\
\text { relevant FinTech. }\end{array}$ \\
\hline $\begin{array}{l}\text { Has the participant singly or jointly borrowed } \\
\text { any money from formal financial institutions } \\
\text { for initiating, running, or growing a business } \\
\text { in the prior year? }\end{array}$ & $\begin{array}{l}\text { Crowdfunding } \\
\text { RegTech } \\
\text { InsurTech } \\
\text { Neobanks }\end{array}$ & $\begin{array}{l}\text { Borrowing for starting or operating a business } \\
\text { corresponds to entrepreneurship and business } \\
\text { management behaviour, which in turn } \\
\text { corresponds to opportunities for FinTech } \\
\text { facilitating business fundraising, insurance, } \\
\text { and regulatory compliance. }\end{array}$ \\
\hline $\begin{array}{l}\text { Has the participant singly or jointly borrowed } \\
\text { in the prior year from: } \\
\text { - a bank or a formal financial } \\
\text { organisation? } \\
\text { - family members, relatives, or friends? } \\
\text { - Informal sources? }\end{array}$ & $\begin{array}{l}\text { Lending services } \\
\text { Personal financial services } \\
\text { InsurTech } \\
\text { RegTech } \\
\text { Neobanks }\end{array}$ & $\begin{array}{l}\text { These items correspond to actual borrowing } \\
\text { behaviour and in turn reflect the possibilities } \\
\text { of FinTech and barriers thereof, especially if } \\
\text { individuals are not accustomed to using } \\
\text { banking services for borrowing. }\end{array}$ \\
\hline
\end{tabular}

Did the participant receive salary/wages from

employers in the prior year in the ways

outlined as options?

Did the participant receive government

payments in the prior year in the ways

outlined as options?

Did the participant receive money from agricultural activities in the prior year in the ways outlined as options?

Payment services

Neobanks
A receipt of payment via a card, in contrast to cash, suggests opportunities for FinTech such as payment services and neobanks.

Did the participant receive money from

self-employment activities in the prior year in

the ways outlined as options?

Options for each of the items are

$$
\begin{aligned}
& \text { as cash } \\
& \text { in a card }
\end{aligned}
$$

The GFD asks participants why they may not have a bank account or an account with a financial institution and suggests reasons, including: distance to financial institutions, financial services being expensive, the lack of documentation to create an account, mistrust about financial institutions, religion, lack of sufficient money, other family members already having an account, and the participant having no need for a formal account. The survey items, in effect, also reflect opportunities for FinTech's expansion as they represent a response to the above-mentioned barriers. The GFD asks participants whether they use cash or online payments to complete their purchases-another survey item that correlates with an opportunity for FinTech technologies. In a similar way, questions asking participants about their borrowing behaviour can be turned around and be considered as an opportunity to develop a FinTech lending service. Questions on borrowing and saving for businesses can be conceptualised as entrepreneurship and business management behaviour. The responses to the survey should be of interest to FinTechs such as crowdfunding services, which may assist raising finance for businesses; or InsurTech, which may be relevant from an insurance perspective; or RegTech, which may assist regulatory compliance. 
In a subsequent step, we analyse and compare SAARC and ASEAN countries with respect to each of the considered questions, that in turn lead to our findings and discussions sections of the article. We use the $\mathrm{R}$ statistical software and relevant packages to conduct all analyses.

\section{Findings}

\subsection{Demography}

Figures 1 and 2 reflect the demographic attributes of the participants to the GFD survey (Demirguc-Kunt et al. 2018; World Bank 2018a) in SAARC and ASEAN countries, as determined from the respective microdata (World Bank 2018b). We note that while the sample size for most countries was approximately 1000, some countries were represented by a larger sample size. Considering this variation in sample size, the subsequent analyses are performed based on percentages of participants, and this allows a reasonable comparison across the relevant countries and regions.

\begin{tabular}{|c|c|}
\hline Country & Total Participants \\
\hline Afghanistan & 1,000 \\
\hline Bangladesh & 1,000 \\
\hline India & 3,000 \\
\hline Nepal & 1,000 \\
\hline Pakistan & 1,600 \\
\hline Sri Lanka & 1,104 \\
\hline SAARC & 8,704 \\
\hline
\end{tabular}

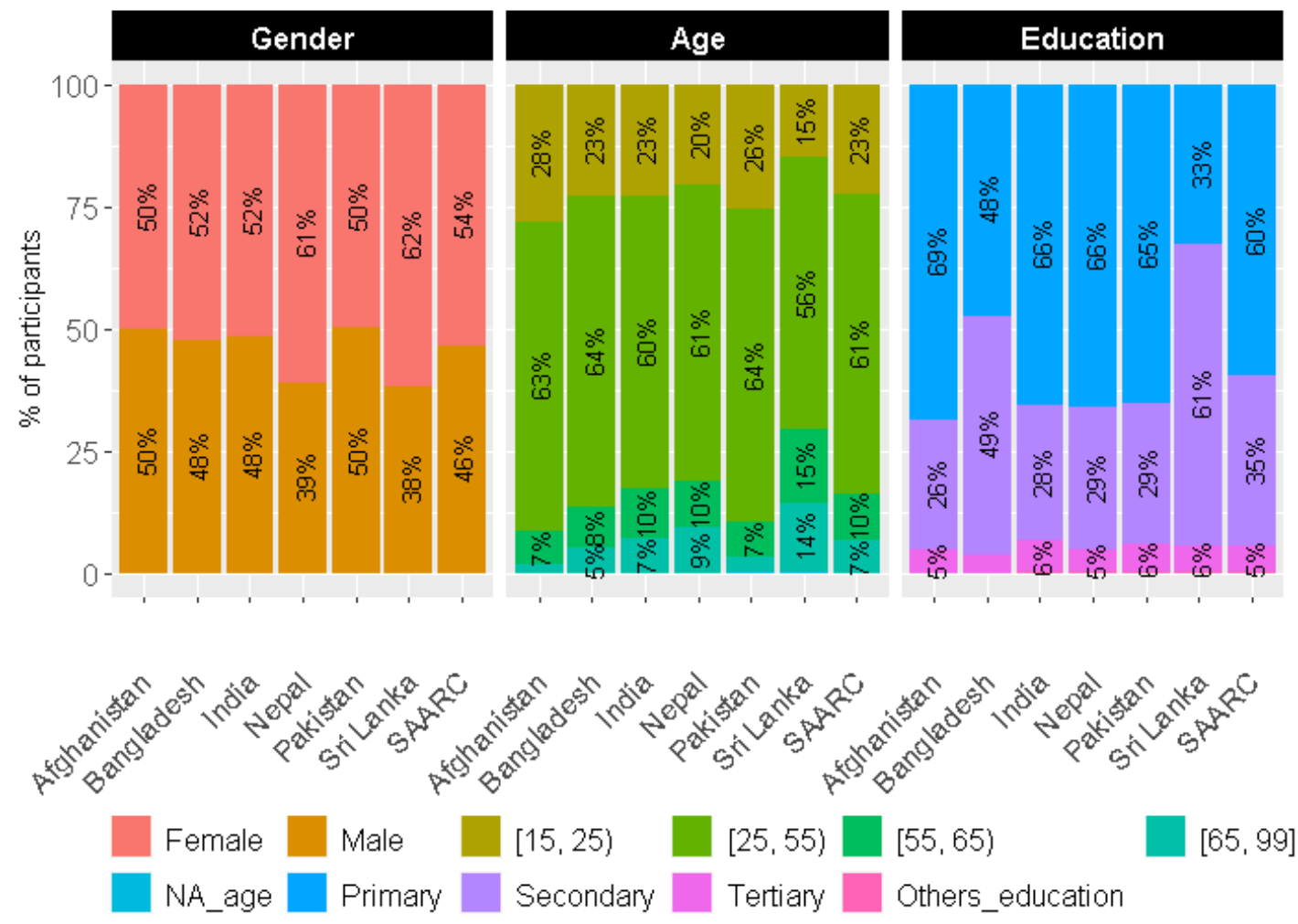

Figure 1. Demographic information of participants from SAARC countries. 


\begin{tabular}{|c|c|}
\hline Country & Total Participants \\
\hline Cambodia & 1,600 \\
\hline Indonesia & 1,000 \\
\hline Lao PDR & 1,000 \\
\hline Malaysia & 1,004 \\
\hline Myanmar & 1,600 \\
\hline Philippines & 1,000 \\
\hline Singapore & 1,000 \\
\hline Thailand & 1,000 \\
\hline Vietnam & 1,002 \\
\hline ASEAN & 10,206 \\
\hline
\end{tabular}
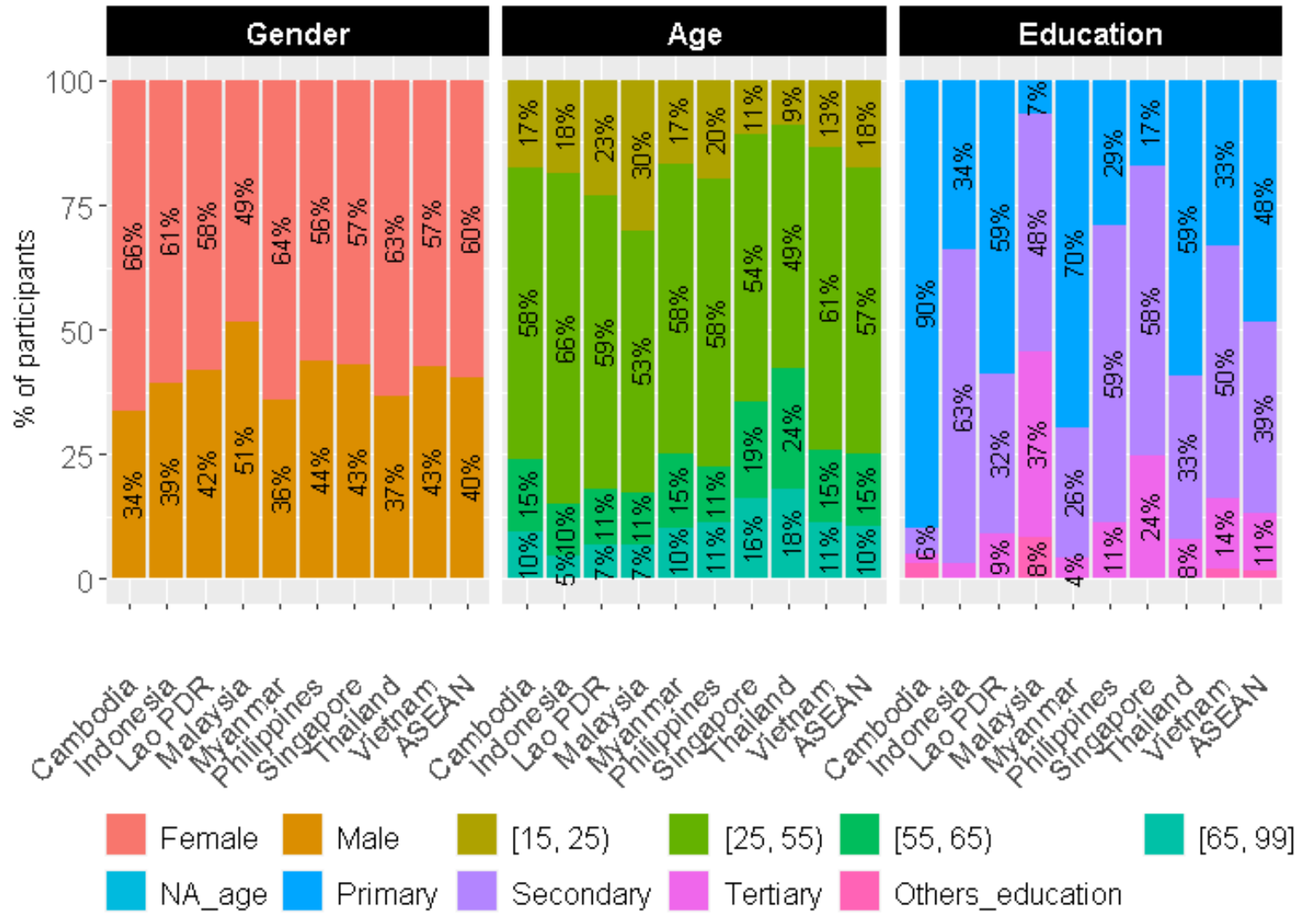

Figure 2. Demographic information of participants from ASEAN countries.

Further to sample size, the demographic attributes of participants across the countries and regions also varied notably (Figures 1 and 2). For SAARC countries, except for Nepal and Sri Lanka, there is a balanced representation of male and female participants. For ASEAN countries, however, most countries had more female than male participants. For countries from both regions, the majority of the participants fall within the $[25,55)$ age group - the age category that involves individuals in the prime of their working life (OECD 2021) (note: $[X, Y)$ implies $X \leq$ Age $<Y$ ). There is also a notable representation of the age group $[15,25)$-the age group of new workers (OECD 2021). There are fewer representations of individuals in the retired age bracket or nearing retirement age $[55,65)$ (OECD 2021) and older people (65+). Age value for a few participants in the different countries is missing. 
Of particular interest is the demographic distribution with respect to education level. The survey recorded participants' education levels across the categories of completing primary education or less, secondary education, and tertiary education or more. A few participants across countries refused to answer the education question or responded as "don't know" or the respective information is missing-these have been grouped in this article as the category "other education". Participants with, at most a primary education level, and those with a secondary education level, constitute the majority across countries. However, multiple ASEAN countries have a higher percentage of participants with a secondary education level than those with an at-most primary education level, except for Bangladesh and Sri Lanka participants where an at-most primary education level exceeds those with secondary levels in SAARC countries. Among ASEAN countries, Malaysia and Singapore have a sizeable percentage of participants with at-least tertiary education levels.

When assessed overall, the demographic patterns for the two country groups (i.e., regions) are comparable with similar percentage representations in terms of gender, age, and education levels.

\subsection{Use of Digital Technologies}

The GFD questionnaire inquired if participants have used a mobile phone or internet for payments, purchases, or cash transactions. This questionnaire item could be linked to the use of digital technology and the responses therefore could be of interest to FinTech services such as payments. The responses could also be of interest for e-commerce and businesses going digital, especially within the ongoing COVID-19 context, who could form partnerships with various FinTech providers such as payment services to ease customer acquisition and financial management. Figure 3 shows the results to this question for both groups of countries.

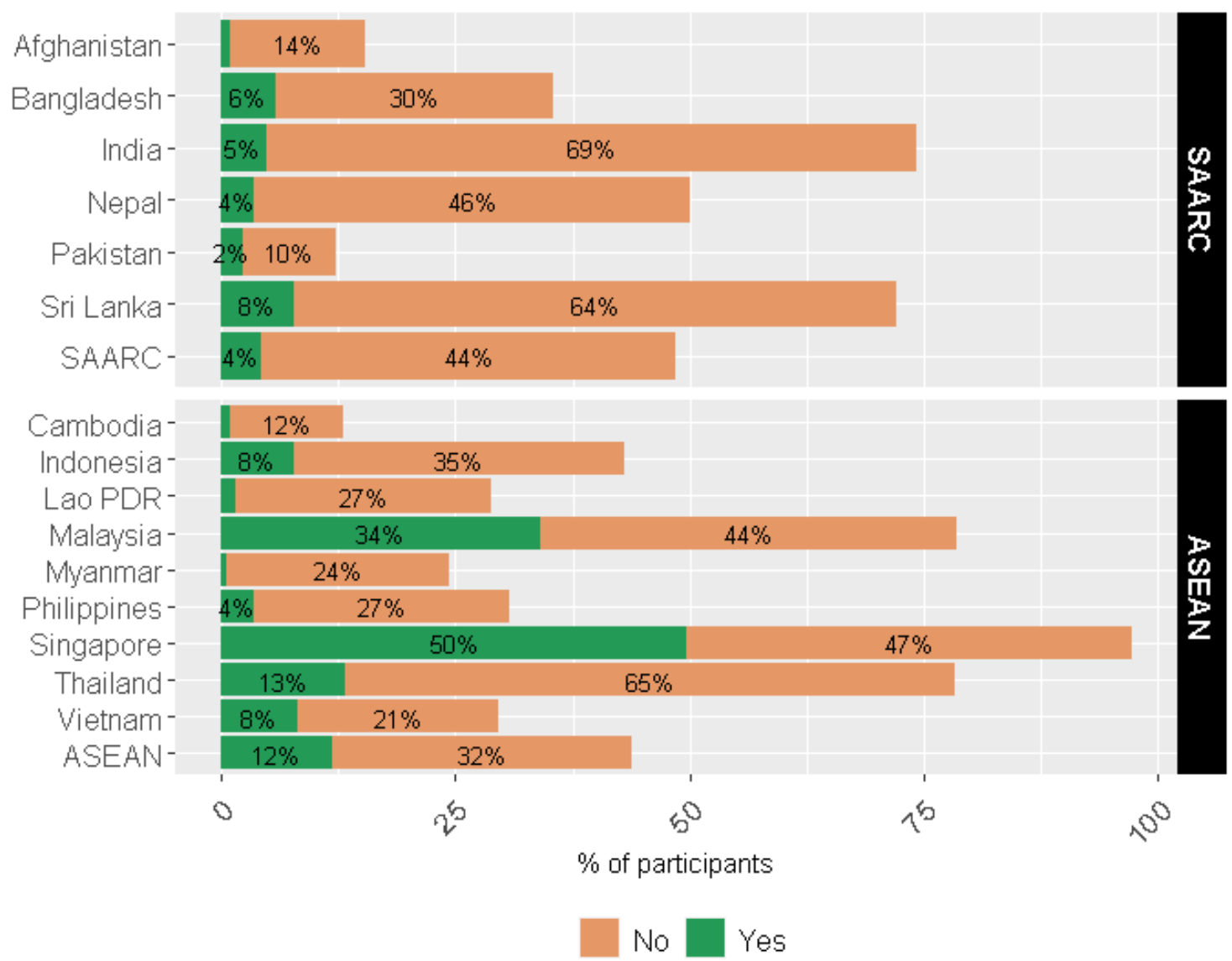

Figure 3. Percentage of participants who used a mobile phone or the internet for payment, purchase, or cash transactions. 
Overall, in 2017, when the GFD survey was published, participants from ASEAN countries appeared to be higher users of digital technologies than those from SAARC countries. Arguably, this difference originates from the socio-economic difference and the education levels reflected by the differences in demographic patterns shown in Figures 1 and 2. Among the ASEAN countries, the main users of digital technologies were from Singapore and Malaysia. There were also notable digital technology users from Thailand, Vietnam, Indonesia, and Bangladesh, with over $5 \%$ of participants using mobile phones, internet payments, purchases, or cash transactions. Thus, for FinTech companies, as of 2017, these countries represent potential markets, especially ASEAN countries.

\subsection{Barriers to Having a Bank Account}

The GFD questionnaire asked participants what they considered to be the main barriers to having a bank account. Such barriers could also be interpreted as opportunities or challenges for FinTech expansion. For instance, a participant indicating financial institutions being far away from their place of residence or viewing such services as expensive may be interested in considering FinTech services as an alternative, especially since mobile money and other FinTech services have often emerged just to address these types of barriers across countries. By contrast, an individual having religious thoughts as a barrier or not feeling the need to have a formal bank account may also perceive the same barriers when considering FinTech services as an alternative. Thus, it is interesting to note how participants from SAARC and ASEAN countries view barriers to having a bank account, and which can then correspond to opportunities and challenges for FinTech expansion in the respective regions.

Figure 4 shows the percentage of participants who responded "yes" to each of the barriers to possessing a bank account. We note that having insufficient funds is indicated as a top barrier by participants from both regions. Unsurprisingly, participants from Singapore were least resistant to having a bank account, while participants from Malaysia, Thailand, and India also indicated having the lowest levels of resistance to possessing a bank account. By contrast, participants from Afghanistan, Cambodia, and the Philippines indicated resistance to having a bank account. The outcome is an indication of the variation in banking and financial context across these countries. From a larger regional perspective, the patterns of barriers have similarities for both the SAARC and ASEAN regions. In both regions, overall, having insufficient funds is the primary barrier. In SAARC regions, the next two most notable barriers relate to financial services being expensive and a view that such services are not needed. Barriers in the ASEAN regions related to missing documentation and financial institutions being too far away, and a perception that such a service were not needed.

\subsection{Savings Behaviour}

The GFD also captures the savings behaviour of participants, and the outcomes should be of interest to different FinTech services. Figure 5 shows the percentage of participants across countries who have saved money using a bank account or similar formal financial institution, and those who saved money by adopting informal approaches such as local saving facilities or people other than family members. Noticeably, participants from Singapore, Malaysia, and Thailand appear to be the higher users of formal bank accounts. This outcome corresponds to the low percentage of participants who indicated a reluctance to having a bank account in Figure 4. Differences were also noted between the two regions. Overall, participants from ASEAN regions appear more accustomed to using formal financial institutions for saving than those from the SAARC regions. From a FinTech expansion perspective, the outcome is interesting. An individual who already uses a formal bank account may feel motivated to consider FinTech alternatives such as personal financial service apps, and neobanks. Those who already use informal approaches, by contrast, may be less inclined to use such services unless the value propositions from FinTech services outweigh the informal offerings already used. From this respect, there 
appears to be greater opportunities for FinTech services in the ASEAN regions than in the SAARC regions.

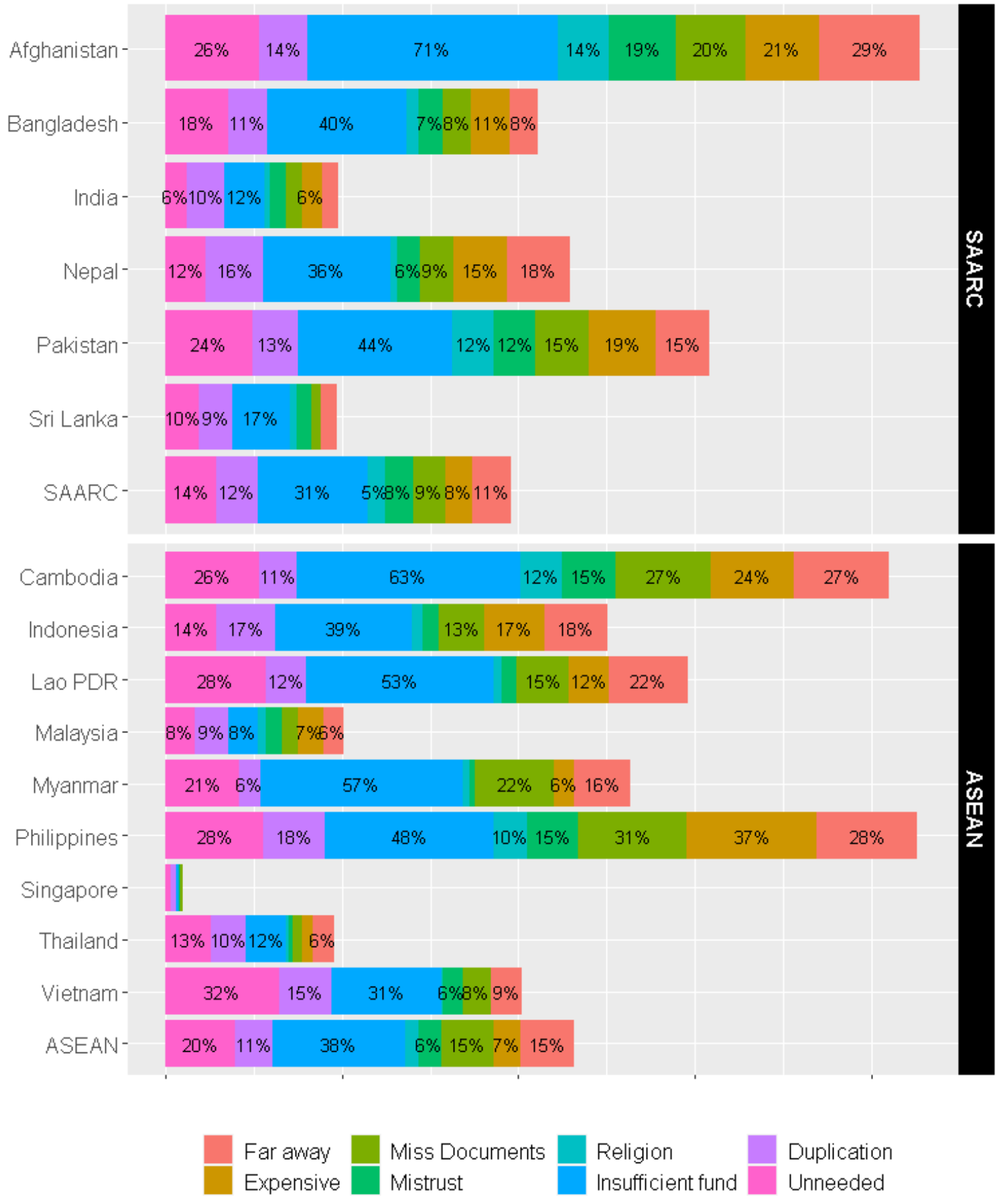

Figure 4. Cumulative percentage of participants indicating barriers to having a bank account.

The GFD survey also asked several savings behaviour questions that would be relevant to FinTech providers. Participants were asked the reasons why they saved money. The two reasons offered were to start or operate a business and to save for old age. Participants who save money for business purposes may be entrepreneurial in nature and therefore may be interested in alternative forms of finance such as crowdfunding. Businesses also need to take out insurance policies and comply with various rules and regulations. Individuals running businesses may consider using FinTechs such as InsurTech (insurance technologies) 
and RegTech (regulatory technologies). Neobanks may also appear as viable alternatives for these individuals, as well as for those who save money for old age. Saving money for old age may open the possibility of providing personal financial services in the FinTech space.

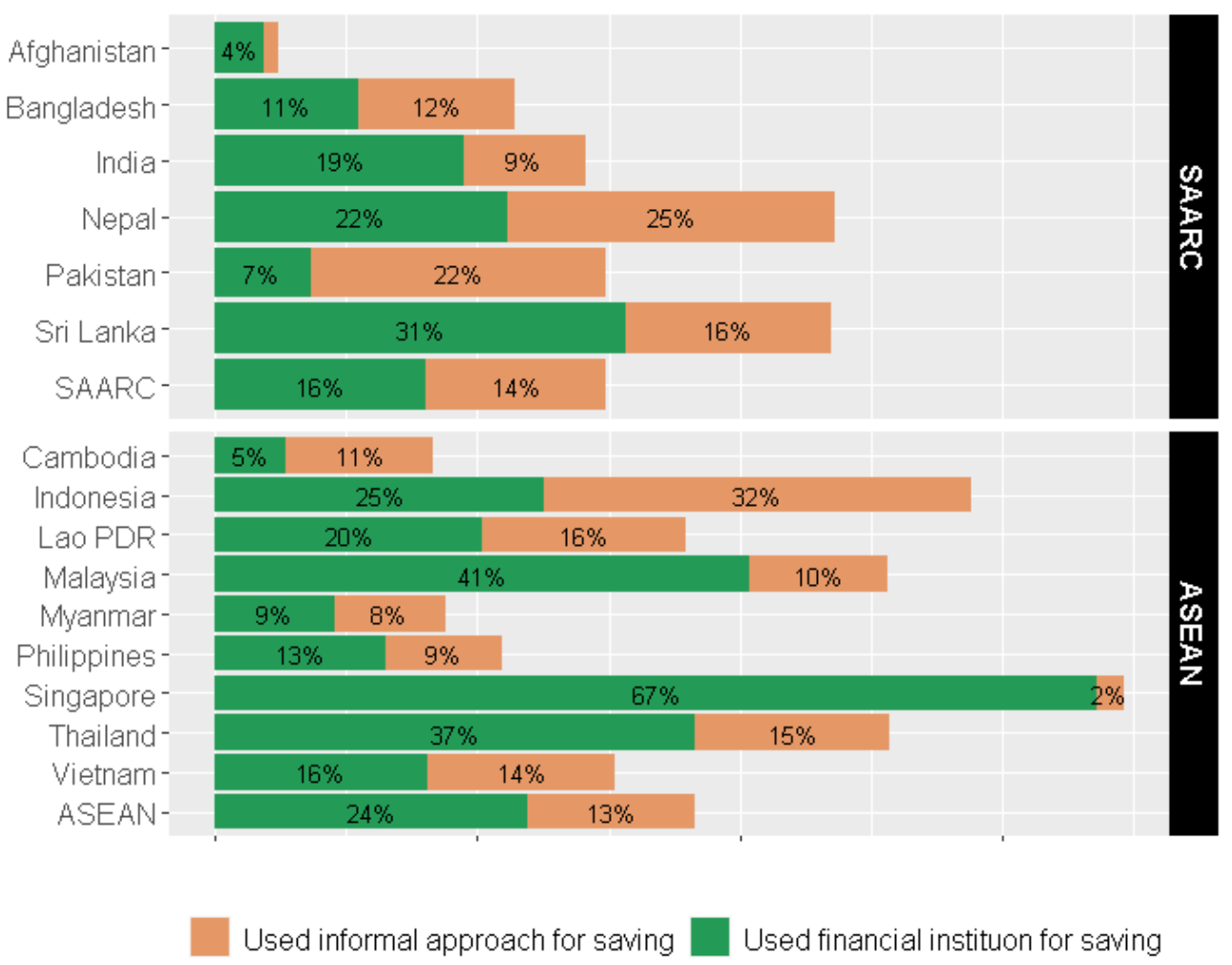

Figure 5. Cumulative percentage of participants who saved money in a bank or a financial institution, and who used informal approaches, such as a group, or a club, or a person beyond the family.

Figures 6 and 7 show the percentage of participants from ASEAN and SAARC regions who saved money to help start a business or for old age. Again, differences in the two regions' socioeconomic contexts influence opportunities and challenges for FinTech services. Participants from these regions generally appear to save money more for old age than business purposes - an indication that personal financial management holds notable potential for FinTech services in these regions. Participants from the Philippines, Thailand, and Vietnam appear to be notable savers of money for business purposes-implying good potential for neobanks, crowdfunding, InsurTech, and RegTech. In contrast, with a lesser percentage of participants saving money for business purposes in the SAARC regions, relevant FinTechs are likely to face greater challenges to expansion in these countries.

\subsection{Borrowing Behaviour}

The GFD also asked participants views on their borrowing behaviour, especially whether they had borrowed money from a formal financial institution such as a bank, informal sources, or from friends, family, and relatives. The questionnaire also gathered information regarding the purpose of borrowing. Figure 8 shows the source of borrowed funds for participants across countries. The pattern of results was like those for saving behaviour. Participants from ASEAN countries showed up as being higher borrowers of funds from banks and financial institutions than participants from SAARC countries. This suggests that potential expansion opportunities for FinTech lending services, such as peer-to-peer lending exist in ASEAN regions. Also, a large percentage of participants in both regions tend to borrow from friends, family, or relatives. This culturally influenced phenomenon could mean that FinTech services may face challenges to expand, especially with convincing people in these two regions to consider FinTech borrowing services. If Fin- 
Tech services can be successfully introduced into some family units then it might convince others to follow suit, especially if this is followed up with word-of-mouth initiatives and various branding strategies.

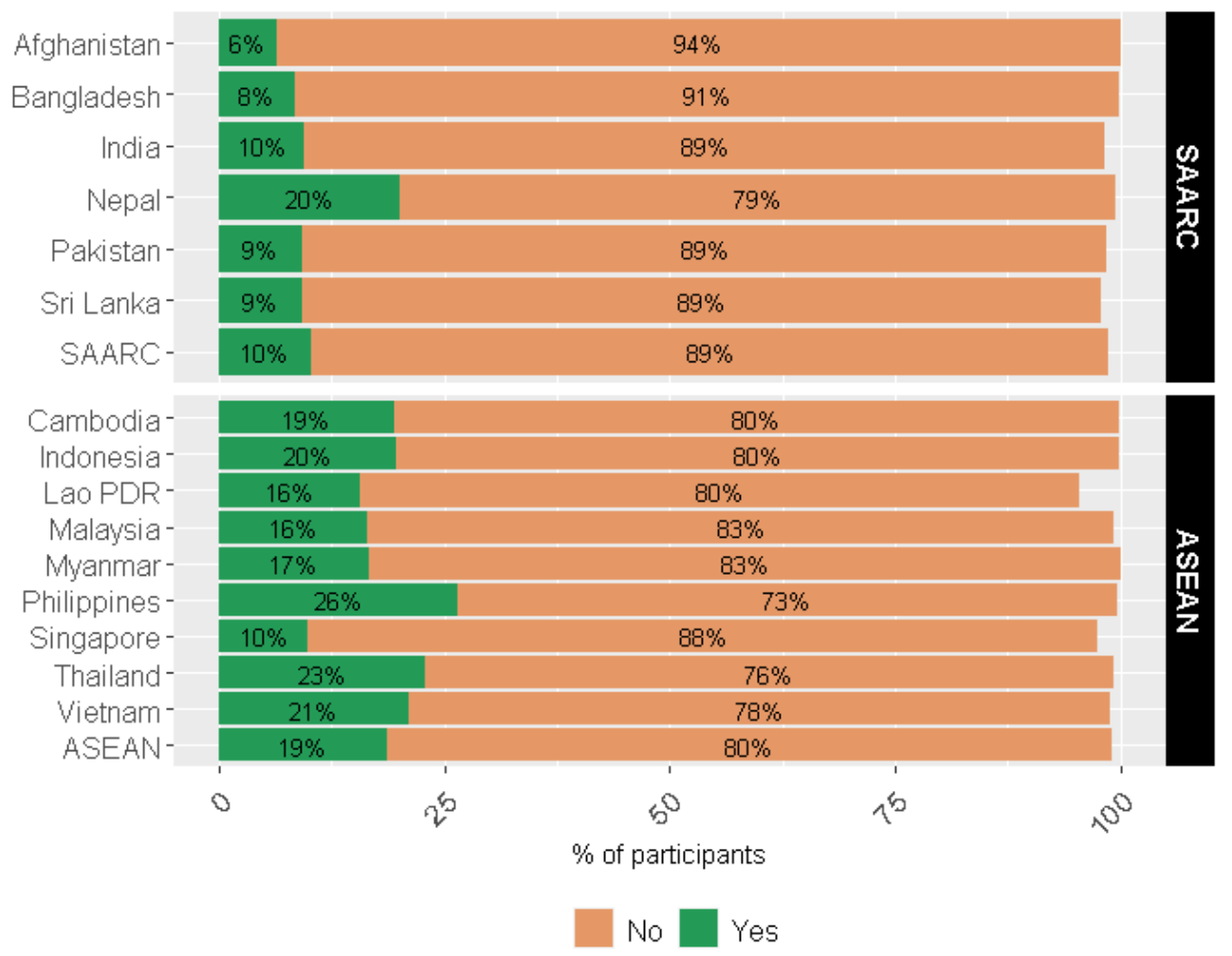

Figure 6. Percentage of participants who saved money for starting or operating a business.

\begin{tabular}{|c|c|c|c|}
\hline Afghanistan- & $8 \%$ & $92 \%$ & \\
\hline Bangladesh- & $10 \%$ & $89 \%$ & \\
\hline India- & $11 \%$ & $88 \%$ & \\
\hline Nepal- & $16 \%$ & $84 \%$ & \\
\hline Pakistan- & $16 \%$ & $80 \%$ & \\
\hline Sri Lanka- & $20 \%$ & $78 \%$ & \\
\hline SAARC - & $13 \%$ & $85 \%$ & \\
\hline \multirow{5}{*}{$\begin{array}{l}\text { Cambodia- } \\
\text { Indonesia- } \\
\text { Lao PDR- } \\
\text { Malaysia- } \\
\text { Muanmar- }\end{array}$} & $21 \%$ & $79 \%$ & \\
\hline & $30 \%$ & $69 \%$ & \\
\hline & $30 \%$ & $66 \%$ & \\
\hline & $44 \%$ & $55 \%$ & \\
\hline & $13 \%$ & $87 \%$ & \\
\hline \multirow{2}{*}{$\begin{array}{l}\text { Philippines - } \\
\text { Singapore- }\end{array}$} & $29 \%$ & $71 \%$ & \\
\hline & \multirow{2}{*}{$\begin{aligned} 55 \% \\
42 \%\end{aligned}$} & \multirow{2}{*}{$\begin{array}{r}43 \% \\
57 \%\end{array}$} & \\
\hline \multirow{4}{*}{$\begin{array}{r}\text { Singapore- } \\
\text { Thailand- } \\
\text { Vietnam- } \\
\text { ASEAN- }\end{array}$} & & & \\
\hline & $21 \%$ & $78 \%$ & \\
\hline & $30 \%$ & $69 \%$ & \\
\hline & $2^{5}$ & $\%$ & $10^{\circ}$ \\
\hline
\end{tabular}

Figure 7. Percentage of participants who saved money for old age. 

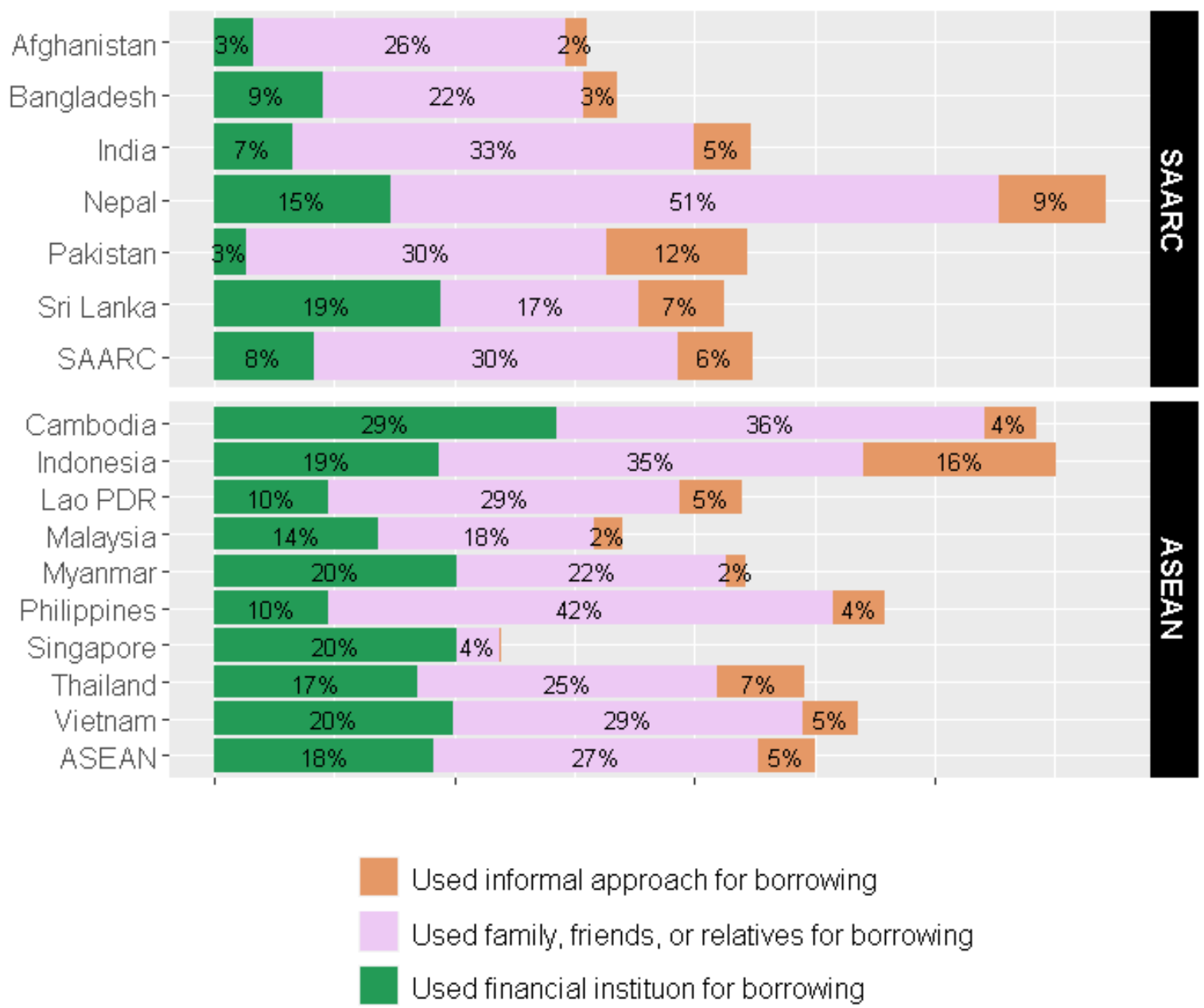

Figure 8. Percentage of participants who borrowed money from a bank or a financial institution, and who borrowed from informal sources, friends or family, or relatives.

Figures 9-11 reflect the percentage of participants who borrow for real estate purchases, health reasons, and business purposes. These results should be of interest to different FinTech organisations. Borrowing to purchase assets coincides with the business interests of neobanks, or other property-oriented FinTech organisations. Borrowing for health reasons should be of interest to InsurTech organisations, especially those offering health insurance services. Lastly, borrowing for business purposes should be of interest to FinTechs such as crowdfunding, RegTech, and InsurTech. Figures 9 and 11 highlight that participants in ASEAN countries are more inclined to borrow money to purchase property or to help start and operate a business than their SAARC counterparts. Figure 10 shows the opposite. That is, participants from SAARC countries are more inclined to borrow for health reasons than those from ASEAN countries. These results indicate that there is potential for FinTech services to be introduced into those markets where gaps exist. 


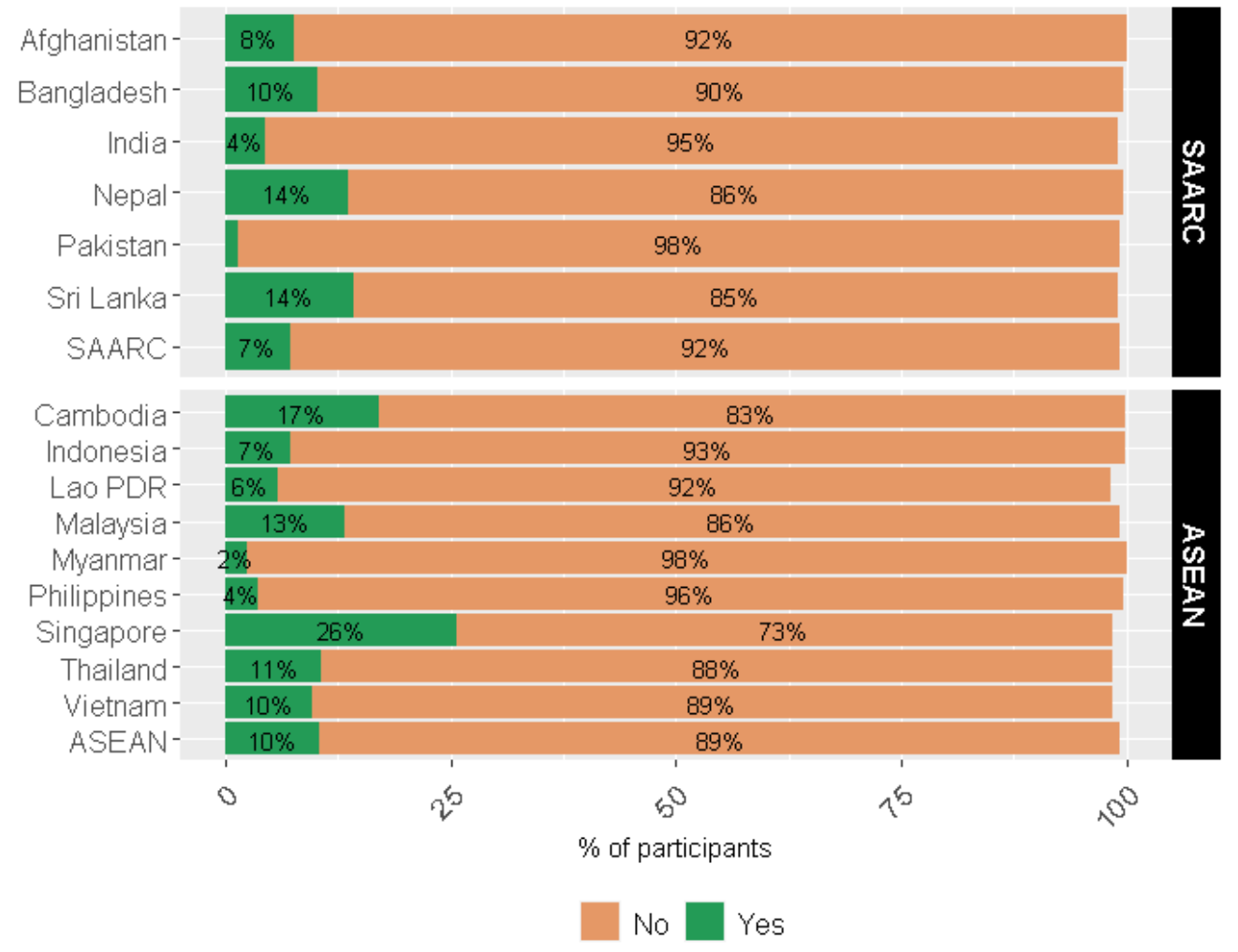

Figure 9. Percentage of participants who borrowed money for purchasing property or land.

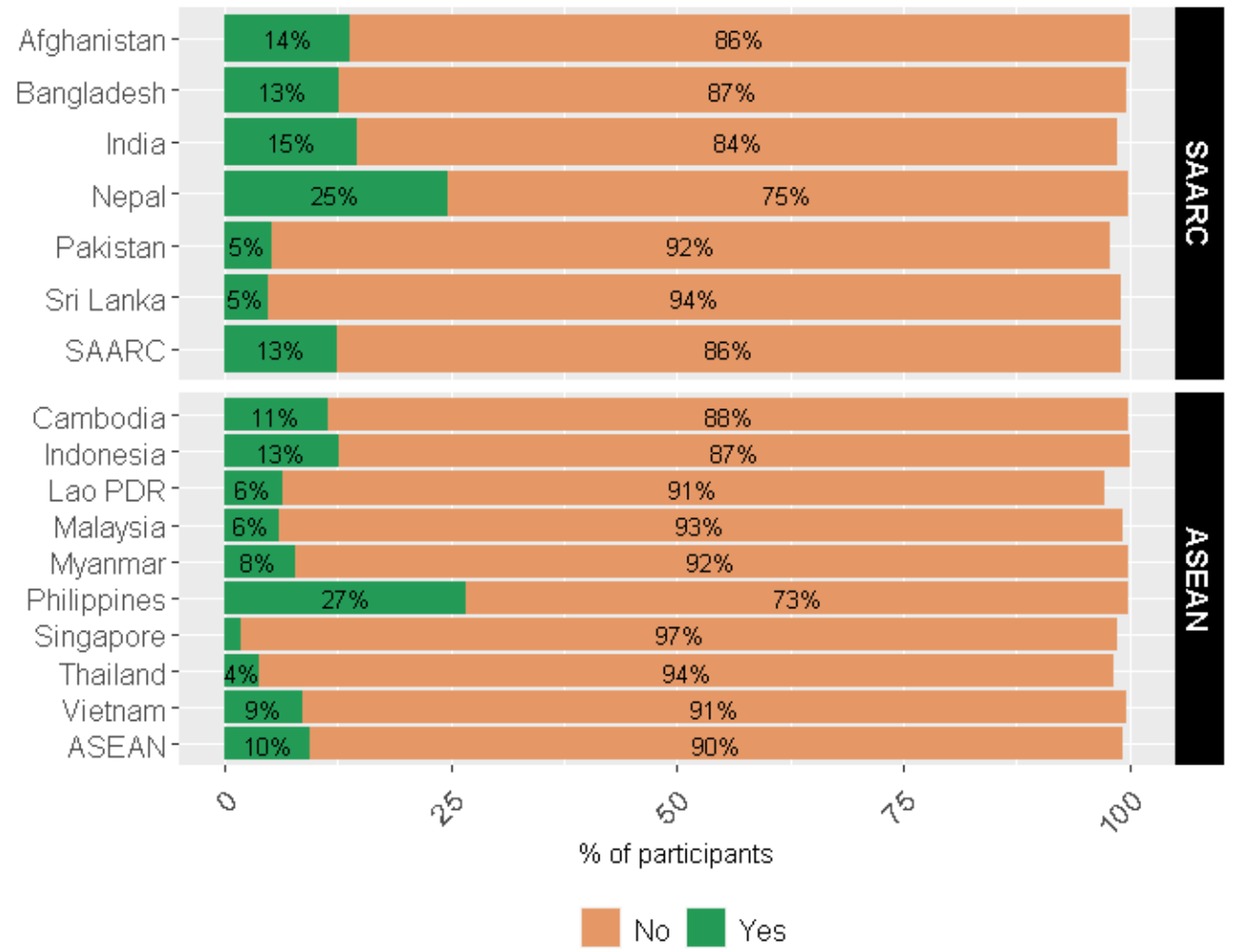

Figure 10. Percentage of participants who borrowed money for medical or health reasons. 


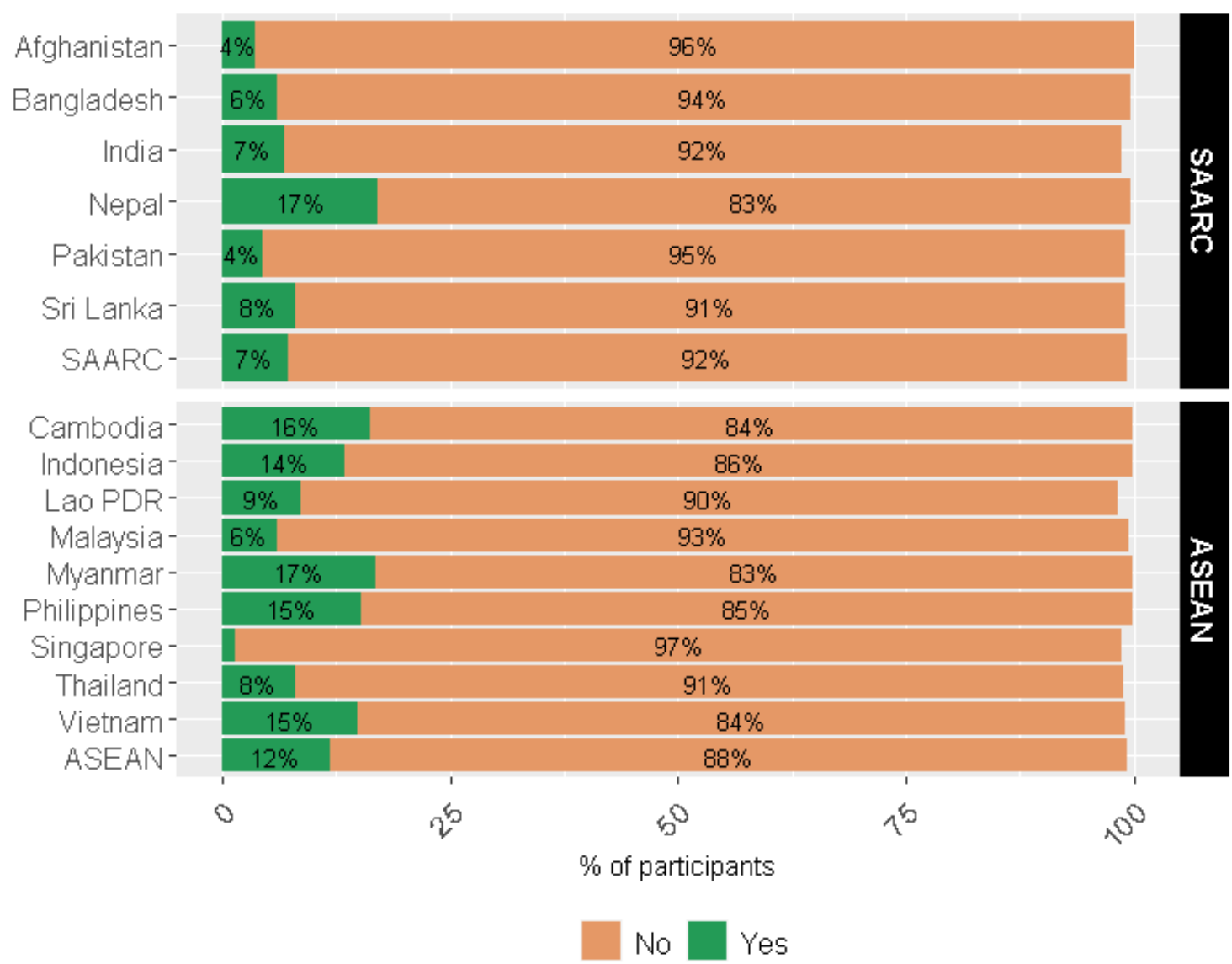

Figure 11. Percentage of participants who borrowed money for starting or operating a business.

\subsection{Receipt of Payments in Cash versus Cards}

The GFD asks participants if they have received certain types of payments directly via cash or card. Using a card linked to a financial institution could imply a tendency to use cashless banking, which would be of interest to those FinTechs that are involved with cashless transactions. Figures 12-15, respectively, indicate the percentage of participants receiving salary, government payments, agricultural activity payments, and self-employment payments via card as opposed to cash. It should be noted that there are several missing values in response to these questions across countries-a reason why low percentages are noted for both mediums of payments. However, as is evident from those who did respond, participants in both regions largely rely on cash for transactions. This outcome is both an opportunity and a barrier for FinTech payment services. On the one hand, an attractive value offering could motivate individuals in the regions to move to cashless FinTech alternatives. On the other hand, shifting such behaviour at a mass scale could be a challenge.

\subsection{Mobile Phone and Mobile Money Account Ownership}

FinTech services are often provided as a mobile phone app, and thus mobile phone ownership can reflect opportunities for penetration into the market. The GFD questionnaire asked participants if they own a mobile phone. The questionnaire also asked participants if they have used a mobile money service, which in turn translates into the potential to initiate various FinTech services. Figure 16 shows that a large percentage of participants in both regions own mobile phones. However, except for Bangladesh, the percentage of participants using mobile money accounts was below $15 \%$ - an indication that while FinTechs have substantial potential for expansion in the regions, the expansion is nowhere near its full potential. Thus, there remain opportunities for FinTech services to plan growth in the respective markets while overcoming various barriers. 


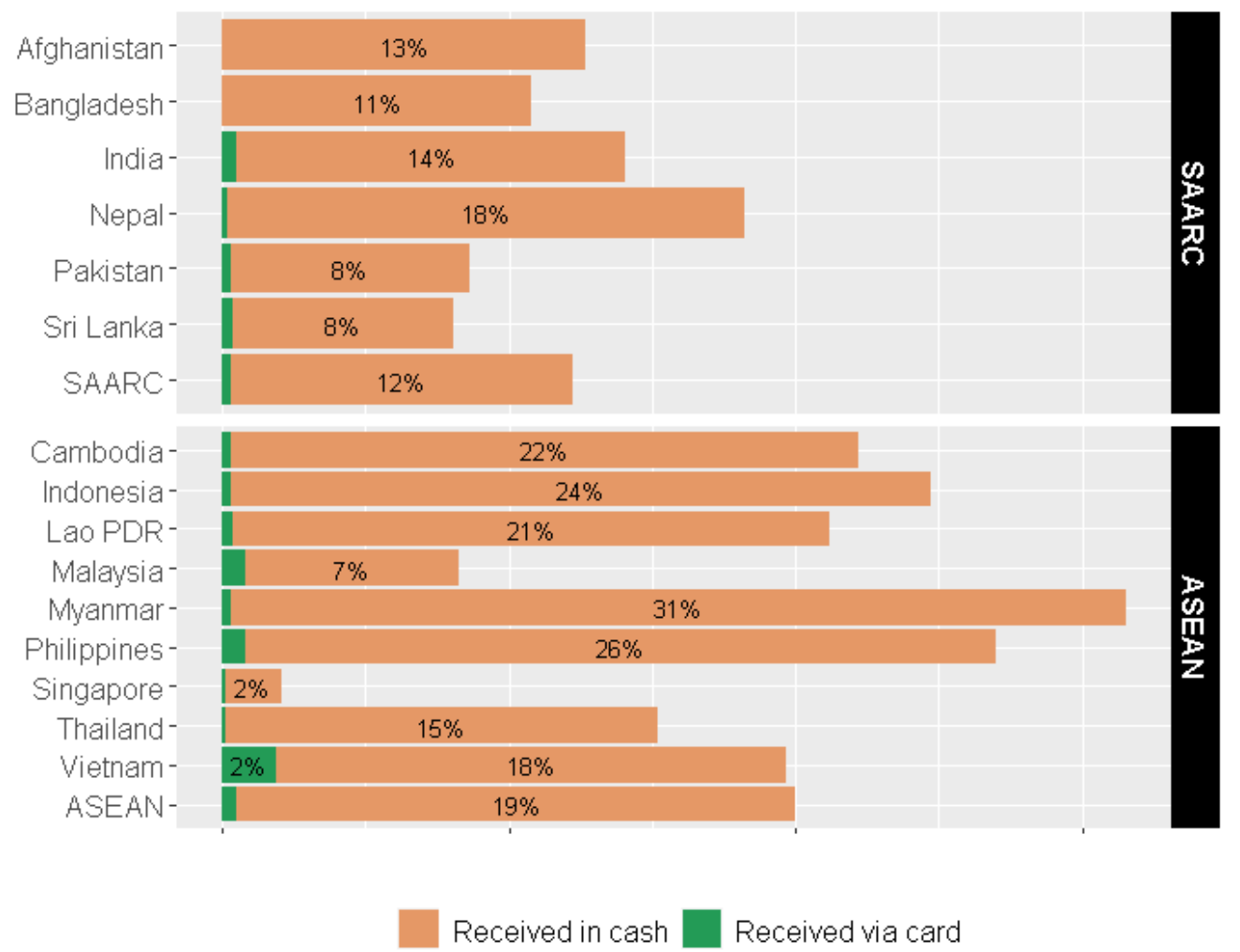

Figure 12. Percentage of participants who received money from employers in cash or via card.

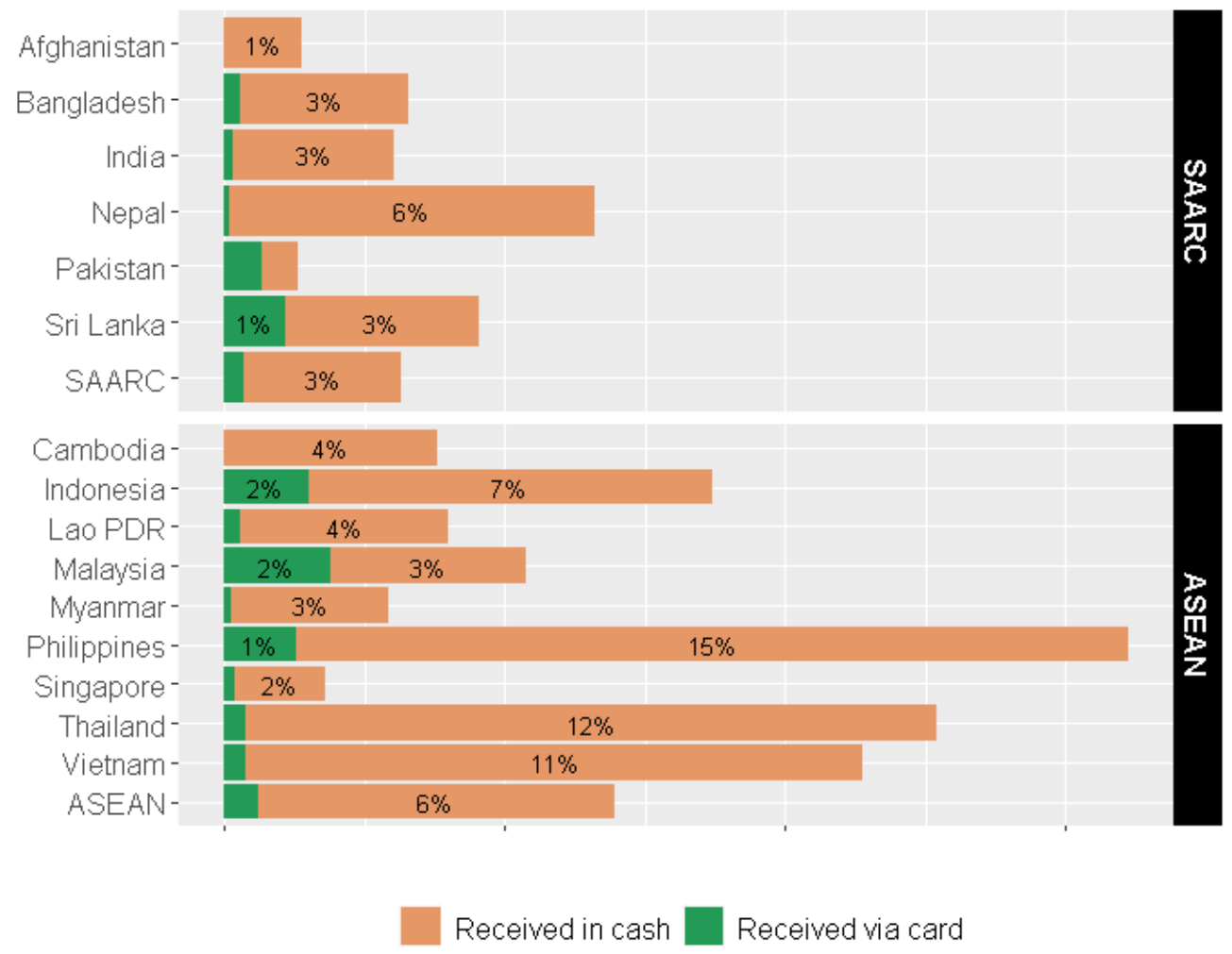

Figure 13. Percentage of participants who received money from government in cash, or via cards. 


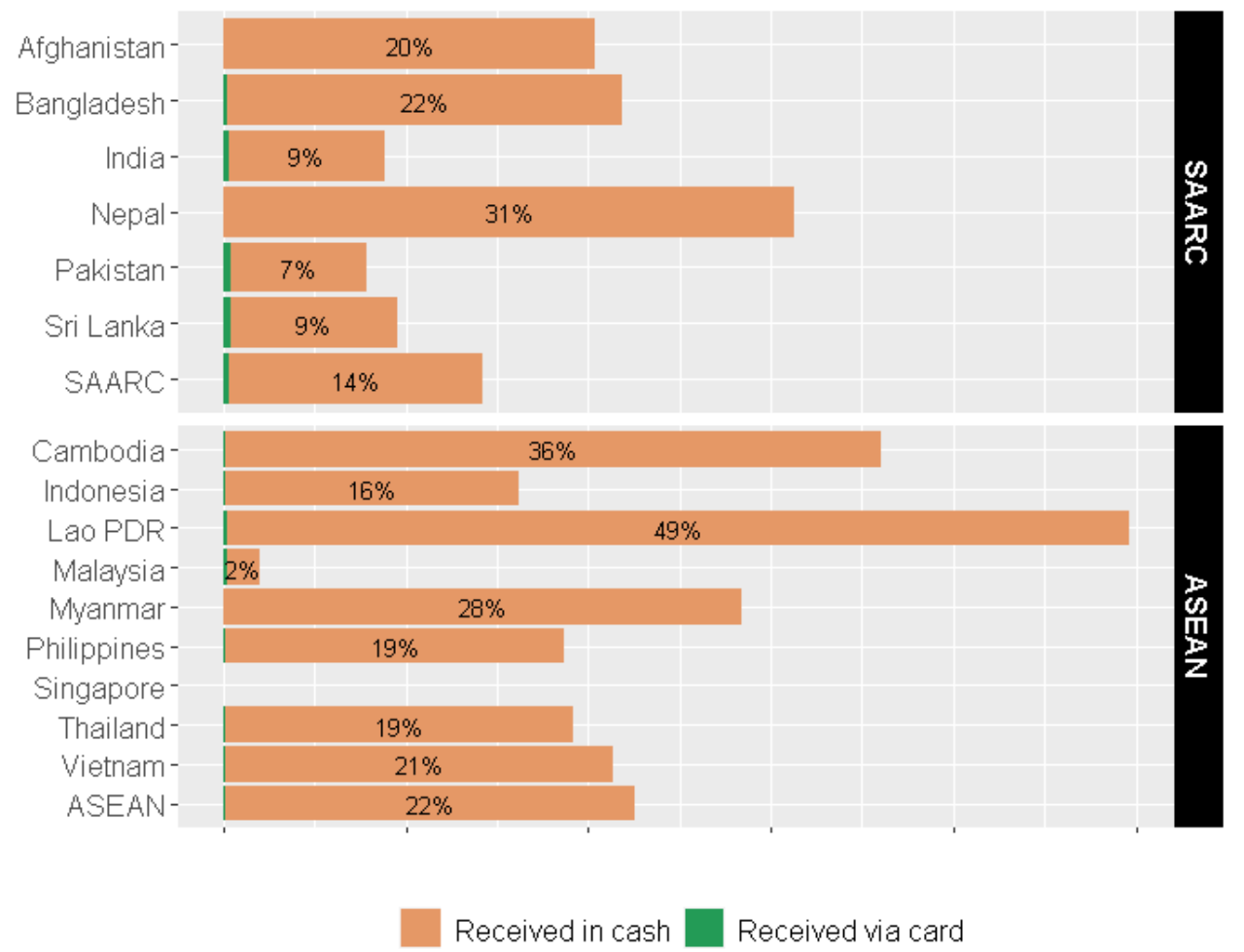

Figure 14. Percentage of participants who received money from agricultural activities in cash, or via cards.

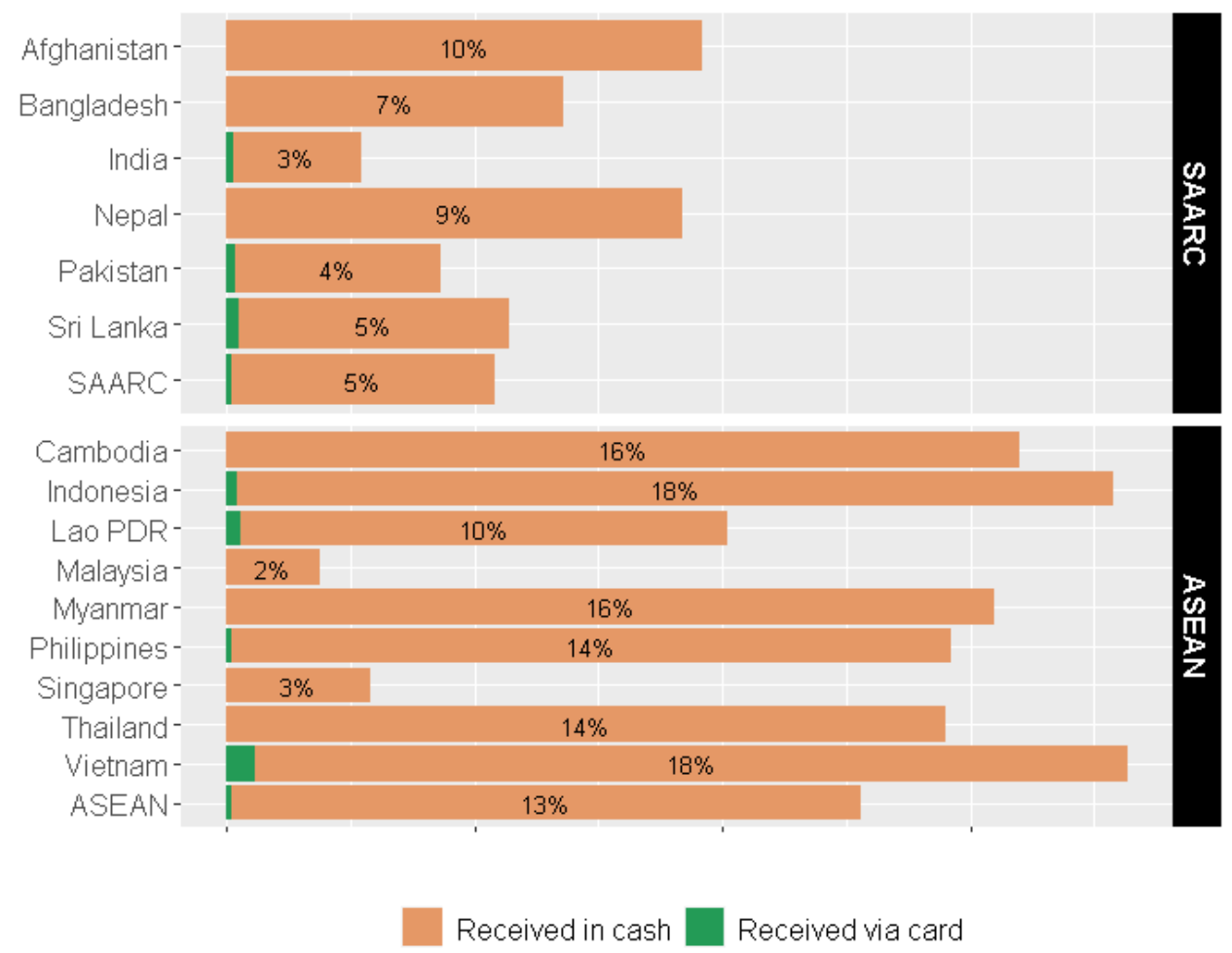

Figure 15. Percentage of participants who received money from self-employment activities in cash, and via cards. 


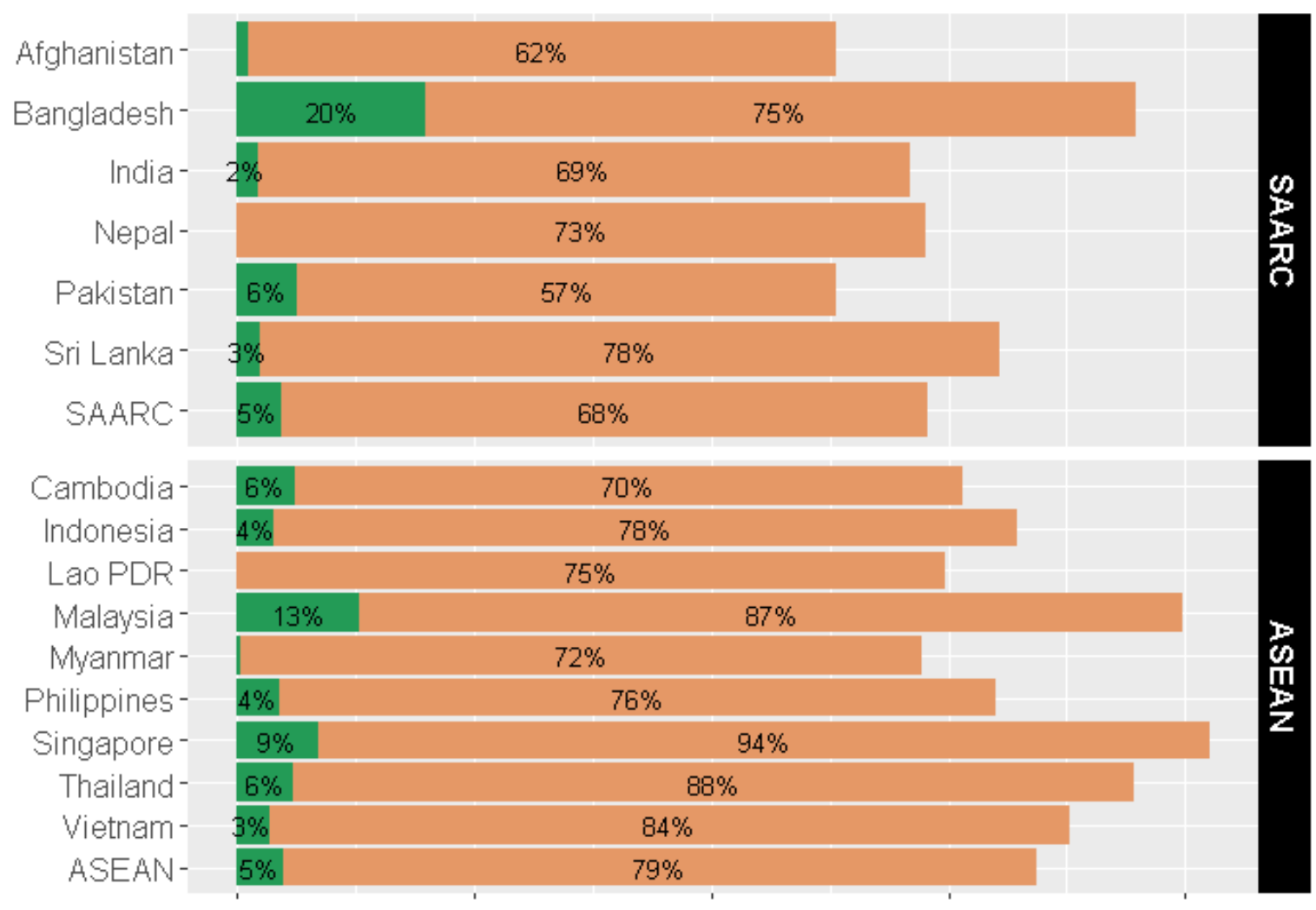

\section{Mobile phone ownership Mobile money account}

Figure 16. Percentage of participants who own a mobile phone, and who possess a mobile money account.

\subsection{FinTech Opportunity Index}

Further to the described statistical analysis, we have summarised the opportunities and barriers for FinTech expansion into the ASEAN and SARRC regions by developing a unique index, which we refer to as the "FinTech Opportunity Index" (FOI). In developing the index, we characterised the borrowing, saving, digital payment usage, payment-receipt behaviour, and the barriers to having a bank account as having either a positive or a negative impact on the expansion of FinTech. We then accumulated the effect in terms of a score. Table 2 shows the score calculation and accompanying explanation, as well as the variable names we used to represent the criteria. The first two and last two criteria, concerning, respectively, account and mobile phone ownership relate to the same GFD question, and, as such, they are both represented by the same criteria variable. In a later part of this subsection, we use the variables to conceptualise the robustness of the proposed index.

Literature in various fields of research refers to different methods of index construction (e.g., Kourlaba and Panagiotakos 2009; Li et al. 2012). Depending on its purpose, a researcher may allocate some scores to variables forming the index or sum scores across survey questions to provide an overview or undertake principal component analysis (PCA) and use the first PCA component to form a composite or index variable or adopt an appropriate multivariate analysis (Abeyasekera 2005). Indeed, a statistical approach was adopted by Huong et al. (2021) in constructing a FinTech adoption index for ASEAN countries. However, while Huong et al. (2021) formed an index based on macro-level or summary data such as total transaction values across different FinTech services and respective total users, we, in this research, have focused on micro-level (i.e., individual level) information concerning financial inclusion. Thus, the information we consider is of a different nature compared to that considered in Huong et al.'s (2021) study. 
Table 2. FOI calculation and explanations.

\begin{tabular}{lll}
\hline $\begin{array}{l}\text { Subjective Behaviour or Indicated Barrier to Financial Inclusion } \\
\text { (the Symbol in the Bracket Represents a Variable Name for the } \\
\text { Respective Criteria) }\end{array}$ & Effect on FOI & Explanation \\
\hline & & $\begin{array}{l}\text { Not having a bank account implies that FinTech } \\
\text { services may be a viable alternative for an } \\
\text { individual. Simultaneously, this may also mean the } \\
\text { individual is not interested in using a formal } \\
\text { financial service- implying that FinTech services } \\
\text { may face challenges in attracting such a customer. }\end{array}$ \\
\hline
\end{tabular}

$\begin{array}{lll}\text { Has a bank account }(C 1) & +1.0 & \begin{array}{l}\text { Having a bank account could imply that FinTech } \\ \text { services may also attract the respective individual. }\end{array}\end{array}$

Does not have a bank account because:

\begin{tabular}{|c|c|c|c|}
\hline - & Far away (C2) & +1.0 & $\begin{array}{l}\text { If financial institutions being far away is } \\
\text { considered a barrier to having a bank account, } \\
\text { FinTech services may appear as a } \\
\text { viable alternative. }\end{array}$ \\
\hline - & Expensive (C3) & +1.0 & FinTech services may offer a cheaper alternative. \\
\hline - & Missing documents $(C 4)$ & +1.0 & $\begin{array}{l}\text { FinTech services may involve fewer administrative } \\
\text { steps. }\end{array}$ \\
\hline - & Mistrust (C5) & -1.0 & $\begin{array}{l}\text { Mistrust for formal financial institutional services } \\
\text { may also impact penetration of the FinTech } \\
\text { services. }\end{array}$ \\
\hline - & Religion (C6) & -1.0 & Same as the barriers associated with mistrust. \\
\hline - & Insufficient funds $(C 7)$ & +0.5 & $\begin{array}{l}\text { Fintech services can often be obtained at a cheaper } \\
\text { cost commitment; however, having insufficient } \\
\text { funds may also lead to individuals not feeling the } \\
\text { need to obtain such services. }\end{array}$ \\
\hline - & Duplication (C8) & -1.0 & $\begin{array}{l}\text { Not having a bank account because another family } \\
\text { member has one may have a similar effect on } \\
\text { FinTech expansion. }\end{array}$ \\
\hline - & Unneeded (C9) & -1.0 & Same as the barriers associated with duplication. \\
\hline
\end{tabular}

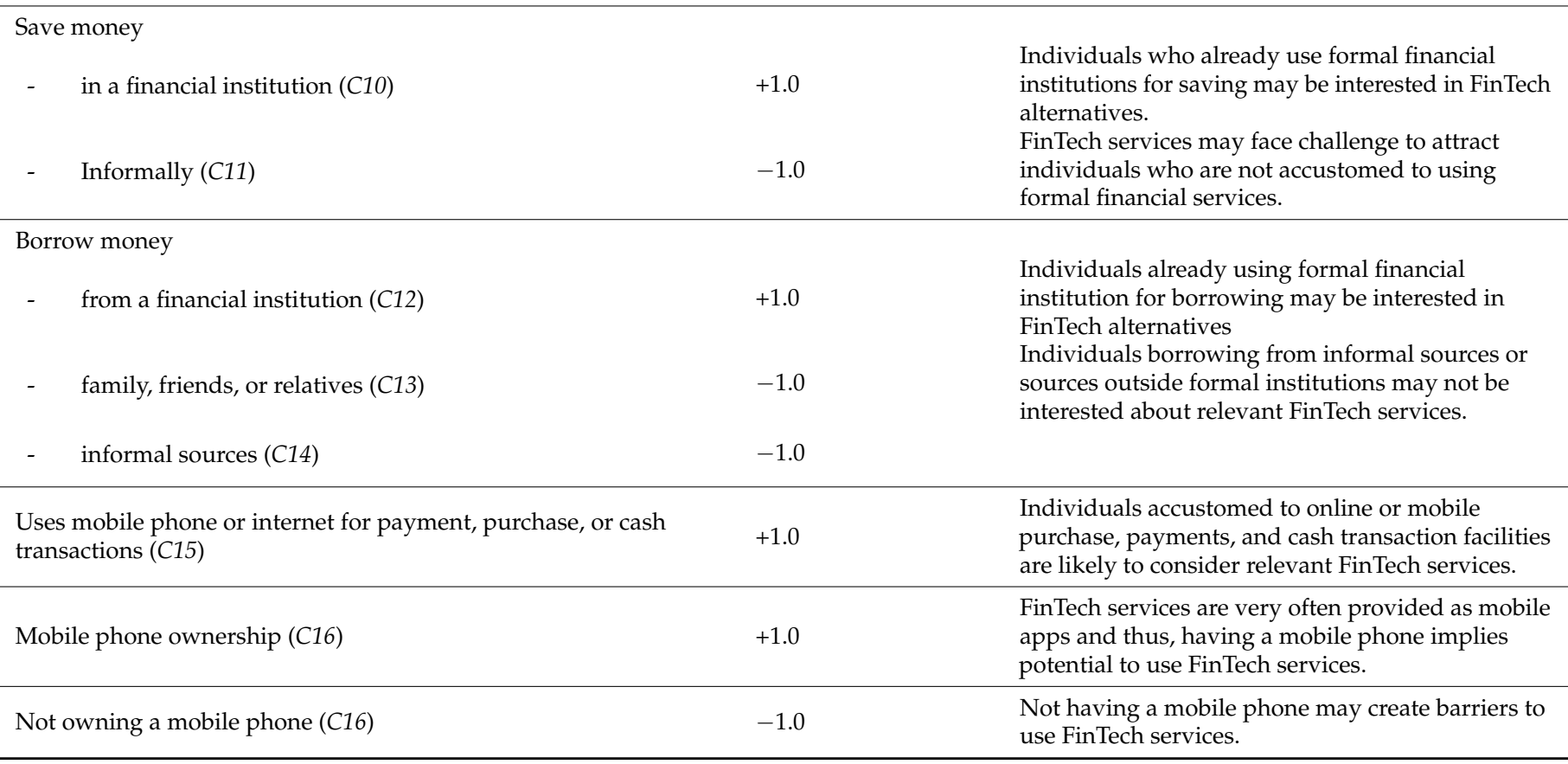

We faced another challenge in creating the index. The GFD survey (Demirguc-Kunt and Klapper 2012; World Bank 2018b) was not conducted specifically to assess FinTech development as it was more geared towards understanding the issues impacting financial inclusion at the individual and country levels. We, in this research, however, interpreted the survey items in terms of opportunities for and barriers to different FinTech services, 
as was explained in the results presented in the prior subsections. In other words, we hold an epistemological orientation similar to interpretivism (Hiller 2016), which is often applied in a qualitative undertaking. Such an interpretivist epistemology expects theories to emerge from data and accommodates knowledge creation in terms of "contextual meanings" (Hiller 2016). Similarly, by working with the quantitative GFD data, we, in this research, interpret the GFD questionnaire in terms of how different FinTech services may appeal to an individual depending on his/her various financial inclusion status and the contextual implications thereof. We then assign the scores indicated in Table 2 based on this interpretation. Overall, our approach corresponds to the approach of assigning scores by a researcher when constructing an index (Abeyasekera 2005). Indeed, such arbitrary scoring based on some judgement for index construction is not uncommon, such as in the health field (Kourlaba and Panagiotakos 2009), and in this research we follow a similar approach.

As noted in Table 2, for each of the financial inclusion criterion, we consider three different scores: $-1.0,0.5,1.0$. There is a rationale behind such choices. For example, an individual may not have a traditional bank account because the financial institution is far away, or he/she feels maintaining a bank account is expensive, or the individual may lack documents to open a bank account. We assume that these individual circumstances may impose a positive impact on our proposed index, since FinTech services have historically often evolved across countries to address these difficulties. Often FinTechs can bring financial services to consumers at a low cost and well within the reach of mobile phones. By contrast, if an individual does not have a bank account because of some subjective mistrust or religious reason(s), the individual may hold a similar belief about FinTech services. Thus, we assume that these financial inclusion criterion may have a negative impact on the index. There are some criteria which could be interpreted as having a neutral effect on FinTech adoption by an individual. For example, if an individual does not have a bank account at all, the individual may adopt FinTechs as an alternative to traditional banking services, provided that the value propositions of FinTech services appeal to him/her. Simultaneously, the lack of bank account may also mean that the individual is not interested in using a formal financial service. This, in turn, implies that FinTech services may face challenges in acquiring the respective individual as a customer. For these grey-area situations, we have assigned a score of 0.5 . With our focus on identifying opportunities for FinTech development in SAARC and ASEAN regions, and this positive score implies a bias towards the possibility of FinTech adoption, while also accommodating the potential barriers for such adoption.

Overall, while the scores assigned are arbitrary, they were chosen upon certain rationales. Our use of subjective interpretation and scores was motivated by the need to gain insights into the opportunities for FinTech services emerging from the GFD information for respective countries and economies. Thus, our epistemological stance is contrary to a positivist epistemological orientation, which is focused on proving a theory. We consider the outcomes of the FOI analysis as supplementary to the descriptive statistical analysis conducted in prior subsections, while also acknowledging the subjectivity in conceptualisation.

We also explore the statistical aspects of the proposed index to conceptualise its robustness. First, we recode the GFD information corresponding to the criteria indicated in Table 2 into binary variables where a value of 1 indicates that the respective criterion has been satisfied. We then determine the Cronbach's alpha (Taber 2018) for the binary variables representing the criteria indicated in Table 2.

Table 3 shows the outcome of assessing Cronbach's alpha. The criterion C15 is excluded due to many missing values not allowing its inclusion in the statistical process. Cronbach's alpha is a reflection of whether a set of variables measure a similar thing, which then justifies their inclusion in designing a composite variable (i.e., an index) (Taber 2018). While there is a traditional view that the Cronbach's alpha for a set of measurement variables should be high and a threshold of at least 0.7 is often recommended, an alternate view argues that a low alpha value does not discount the usefulness of the respective measures and there needs to be a focus on an interpretation of the measures (Taber 2018). We note 
in Table 3 that the alpha value for the criteria composing the FOI is below 0.7, however the value of 0.54 falls within the "acceptable" or "sufficient" range outlined in some works (Taber 2018). We, therefore, undertook further analysis on the robustness of the FOI.

Table 3. Cronbach's alpha for the variables characterising FOI.

\begin{tabular}{|c|c|c|c|}
\hline $\begin{array}{c}\text { Standardised Alpha } \\
\text { When Considering } \\
\text { All Criteria }\end{array}$ & $\begin{array}{c}\text { Average } \\
\text { Inter-Correlation } \\
\text { between Criteria }\end{array}$ & Criteria & $\begin{array}{c}\text { Standardised Alpha } \\
\text { If the Criteria Are } \\
\text { Dropped }\end{array}$ \\
\hline 0.54 & 0.07 & $\begin{array}{l}\text { C1 } \\
\text { C2 } \\
\text { C3 } \\
\text { C4 } \\
\text { C5 } \\
\text { C6 } \\
\text { C7 } \\
\text { C8 } \\
\text { C9 } \\
\text { C10 } \\
\text { C11 } \\
\text { C12 } \\
\text { C13 } \\
\text { C14 } \\
\text { C16 }\end{array}$ & $\begin{array}{l}0.51 \\
0.50 \\
0.49 \\
0.51 \\
0.51 \\
0.52 \\
0.54 \\
0.53 \\
0.52 \\
0.52 \\
0.52 \\
0.53 \\
0.53 \\
0.50 \\
0.53\end{array}$ \\
\hline
\end{tabular}

Table 4 shows the correlation matrix for the binary coded criteria variables and the FOI. Of particular interest are the correlation coefficients of between FOI and the criteria variables. We note that the coefficients are all statistically significant. As explained earlier, the FOI was developed using composite assigned scores based on the criteria and not upon the binary criteria variables themselves. Thus, the outcome that the FOI is statistically related to all criteria is an indication of the subjective scores' suitability in developing the index. Furthermore, the interpretation of the coefficients makes sense. For example, the coefficient between the FOI and C16 (mobile phone ownership) is 0.60-implying that there is a reasonably strong positive relationship between an individual having mobile phones and adopting FinTech services. On the same note, we observed a statistically negative relationship between the FOI and C14 (an individual prefers to borrow from informal sources rather than formal financial services) - which also makes sense, since such individuals may not feel comfortable adopting FinTech services. The other coefficients can be interpreted similarly. Moreover, as noted in Tables 3 and 4, the correlation coefficient between the criteria variable is low on average. This is an indication that the proposed composite variable (i.e., FOI) is not significantly affected by intercorrelations between the constituent criteria variables, and therefore supports the notion that the FOI could act as a potential measure to characterise the adoption opportunities of FinTech services in all regions.

Figure 17 shows the distribution of the FOI across the countries by boxplots, with the middle bar indicating the median. We note that, except for Sri Lanka, the FOI in SAARC countries has tended to remain at similar median levels. The median FOI for ASEAN countries overall exceeds that of SAARC countries, an indication that FinTech services appear to have a higher opportunity in the ASEAN regions as compared to the SAARC regions. We gain further insights concerning the FOI in the next section. 
Table 4. Correlation matrix between criterion variables and the FOI. The bolded values are statistically significant at $95 \%$ confidence level.

\begin{tabular}{|c|c|c|c|c|c|c|c|c|c|c|c|c|c|c|c|c|c|}
\hline & $C 1$ & $C 2$ & $C 3$ & $C 4$ & C5 & C6 & $C 7$ & $C 8$ & $C 9$ & $C 10$ & C11 & $C 12$ & $C 13$ & C14 & C15 & $C 16$ & FOI \\
\hline$C 1$ & 1.00 & & & & & & & & & & & & & & & & \\
\hline C2 & -0.02 & 1.00 & & & & & & & & & & & & & & & \\
\hline C3 & 0.02 & 0.38 & 1.00 & & & & & & & & & & & & & & \\
\hline C4 & 0.00 & 0.24 & 0.24 & 1.00 & & & & & & & & & & & & & \\
\hline C5 & 0.03 & 0.21 & 0.29 & 0.18 & 1.00 & & & & & & & & & & & & \\
\hline C6 & 0.01 & 0.15 & 0.19 & 0.13 & 0.29 & 1.00 & & & & & & & & & & & \\
\hline$C 7$ & 0.00 & 0.13 & 0.13 & 0.11 & 0.04 & 0.02 & 1.00 & & & & & & & & & & \\
\hline $\mathrm{C} 8$ & 0.06 & 0.09 & 0.08 & 0.05 & 0.10 & 0.02 & -0.05 & 1.00 & & & & & & & & & \\
\hline C9 & 0.02 & 0.17 & 0.16 & 0.11 & 0.13 & 0.07 & 0.06 & 0.16 & 1.00 & & & & & & & & \\
\hline C10 & 0.43 & 0.01 & 0.01 & 0.00 & 0.03 & 0.00 & -0.04 & 0.09 & 0.01 & 1.00 & & & & & & & \\
\hline C11 & 0.07 & 0.01 & 0.00 & -0.02 & 0.00 & -0.01 & -0.02 & 0.05 & 0.01 & 0.10 & 1.00 & & & & & & \\
\hline C12 & 0.13 & 0.02 & 0.02 & 0.04 & -0.01 & -0.01 & 0.05 & -0.02 & -0.01 & 0.15 & 0.08 & 1.00 & & & & & \\
\hline C13 & 0.00 & 0.05 & 0.07 & 0.04 & 0.02 & 0.02 & 0.09 & -0.03 & -0.03 & -0.02 & 0.13 & 0.07 & 1.00 & & & & \\
\hline C14 & 0.18 & 0.01 & 0.05 & -0.01 & -0.02 & 0.01 & -0.11 & 0.08 & 0.00 & 0.15 & 0.39 & 0.13 & 0.23 & 1.00 & & & \\
\hline C15 & & & & & & & & & & 0.24 & 0.03 & 0.09 & -0.04 & 0.01 & 1.00 & & \\
\hline C16 & 0.23 & -0.01 & -0.01 & 0.00 & 0.02 & -0.03 & 0.03 & 0.04 & 0.06 & 0.19 & 0.08 & 0.08 & 0.05 & 0.09 & 0.16 & 1.00 & \\
\hline FOI & 0.36 & 0.30 & 0.27 & 0.31 & -0.13 & -0.16 & 0.23 & -0.24 & -0.21 & 0.44 & -0.24 & 0.29 & -0.27 & -0.34 & 0.49 & 0.60 & 1.00 \\
\hline
\end{tabular}

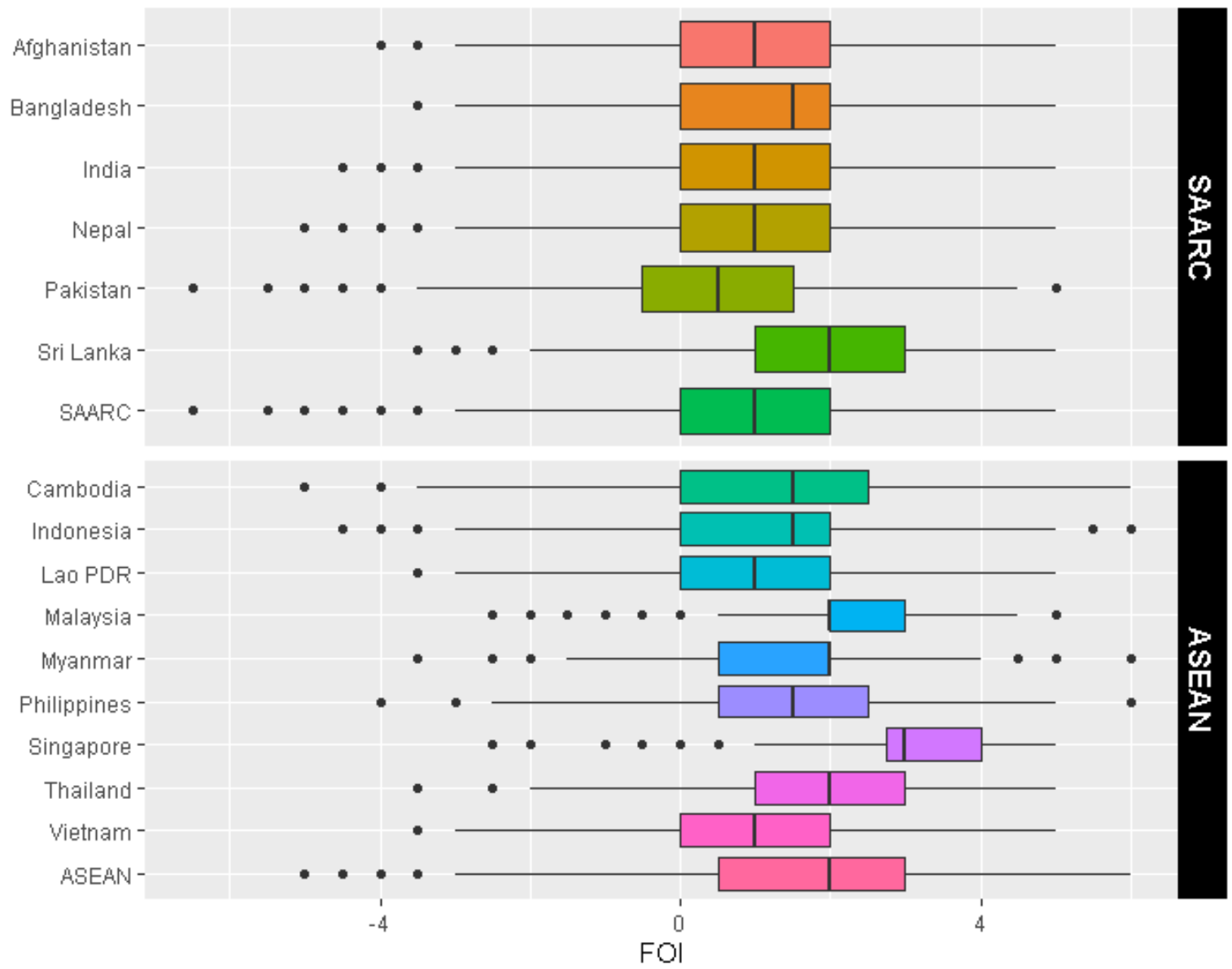

Figure 17. Distribution of the FinTech Opportunity Index (FOI). 


\subsection{Regression Analysis}

We conducted a regression analysis to understand the impact of demographic factors on opportunities for FinTech services, conceptualised by the FOI, in SAARC and ASEAN countries. We considered the following model:

$$
\mathrm{FOI}_{i j}=\text { Gender }_{i j}+\text { Age }_{i j}+\text { Education }_{i j}+\varepsilon_{i j}
$$

Thus, for an individual $i$ from country $j$, we assume that the individual's gender, age group, and education level have an impact on the FOI for that individual. As discussed in the previous section, the FOI inherently considers individualistic saving and borrowing behaviour, perceptions about barriers to financial inclusion, and ownership of mobile phone and bank accounts to capture the opportunities for FinTech services. Thus, Equation (1) extends the previous analysis by also capturing the demographic impact on FinTech opportunities. We conducted a regression analysis based on Equation (1) for both SAARC and ASEAN countries separately, as well as a pooled regression combining information from both groups of countries.

Additionally, we consider that the country an individual is from will also have an impact on the business context of FinTech services. Consequently, further to Equation (1), we consider a fixed-effect panel data model as shown in Equation (2) which inherently captures the effects of country level variables such as GDP, innovation, labour market status, inflation, interest rate, and other macro and micro-economic variables.

$$
\mathrm{FOI}_{i j}=\text { Gender }_{i j}+\text { Age }_{i j}+\text { Education }_{i j}+\text { Country }_{j}+\varepsilon_{i j}
$$

Table 5 shows the regression outcome. We note that the models are statistically significant, as evident from the F-scores. Also, while the $\mathrm{R}^{2}$ values are low, the residual standard error is within \pm 1.52 , implying that the model deviates from the true FOI only by a small margin.

Table 5. Regression outcomes for SAARC, ASEAN, and combined-data (Equation (1)), and fixed-effect

\begin{tabular}{|c|c|c|c|c|}
\hline & \multicolumn{4}{|c|}{ Dependent Variable } \\
\hline & \multicolumn{4}{|c|}{ FOI } \\
\hline & SAARC & ASEAN & Combined & Fixed Effect \\
\hline Gender: Male & $\begin{array}{c}0.353^{* * *} \\
(0.032)\end{array}$ & $\begin{array}{c}0.144^{* * *} \\
(0.031)\end{array}$ & $\begin{array}{c}0.195^{* * *} \\
(0.022)\end{array}$ & $\begin{array}{c}0.273^{* * *} \\
(0.021)\end{array}$ \\
\hline Age: $[25,55)$ & $\begin{array}{c}0.209 * * * \\
(0.039)\end{array}$ & $\begin{array}{c}0.145^{* * *} \\
(0.041)\end{array}$ & $\begin{array}{c}0.209 * * * \\
(0.029)\end{array}$ & $\begin{array}{c}0.122^{* * *} \\
(0.027)\end{array}$ \\
\hline Age: $[55,65)$ & $\begin{array}{l}0.107 * \\
(0.061)\end{array}$ & $\begin{array}{c}0.160 * * * \\
(0.054)\end{array}$ & $\begin{array}{c}0.265^{* * *} \\
(0.041)\end{array}$ & $\begin{array}{l}-0.033 \\
(0.039)\end{array}$ \\
\hline Age: $[65,99]$ & $\begin{array}{l}-0.012 \\
(0.070)\end{array}$ & $\begin{array}{c}-0.295^{* * *} \\
(0.060)\end{array}$ & $\begin{array}{l}-0.059 \\
(0.046)\end{array}$ & $\begin{array}{c}-0.431 * * * \\
(0.044)\end{array}$ \\
\hline Education: Primary & $\begin{array}{c}0.139 \\
(0.421)\end{array}$ & $\begin{array}{c}0.463^{* * *} \\
(0.123)\end{array}$ & $\begin{array}{c}0.184 \\
(0.117)\end{array}$ & $\begin{array}{c}0.577^{* * *} \\
(0.114)\end{array}$ \\
\hline Education: Secondary & $\begin{array}{l}0.731 * \\
(0.422)\end{array}$ & $\begin{array}{c}0.966^{* * *} \\
(0.124)\end{array}$ & $\begin{array}{c}0.795^{* * *} \\
(0.118)\end{array}$ & $\begin{array}{c}0.965^{* * *} \\
(0.114)\end{array}$ \\
\hline Education: Tertiary & $\begin{array}{c}1.179 * * * \\
(0.426)\end{array}$ & $\begin{array}{c}1.767^{* * *} \\
(0.129)\end{array}$ & $\begin{array}{c}1.572 * * * \\
(0.123)\end{array}$ & $\begin{array}{c}1.530 * * * \\
(0.117)\end{array}$ \\
\hline Constant & $\begin{array}{c}0.305 \\
(0.423)\end{array}$ & $\begin{array}{l}0.710 * * * \\
(0.126)\end{array}$ & $\begin{array}{c}0.588^{* * *} \\
(0.119)\end{array}$ & \\
\hline Observations & 8702 & 10,204 & 18,906 & 18,906 \\
\hline Adjusted R ${ }^{2}(\%)$ & $7.0 \%$ & $8.8 \%$ & $8.4 \%$ & $6.1 \%$ \\
\hline Residual Std. Error & 1.458 & 1.519 & 1.518 & \\
\hline F Statistic & $\begin{array}{c}94.214^{* * *} \\
(\mathrm{df}=7 ; 8694)\end{array}$ & $\begin{array}{c}140.931^{* * *} \\
(\mathrm{df}=7 ; 10,196)\end{array}$ & $\begin{array}{c}249.804^{* * *} \\
(\mathrm{df}=7 ; 18,898)\end{array}$ & $\begin{array}{c}178.652 * * * \\
(\mathrm{df}=7 ; 18,884)\end{array}$ \\
\hline
\end{tabular}
models (Equation (2)). 
We also consider the influence that demographic attributes have on the FOI. We note that gender has a statistically significant positive impact on the FOI, irrespective of the country group and regression and fixed-effect analysis (Table 3). This is an indication that, in the regions considered in this research, males are more likely to adopt FinTech services than females. Furthermore, the analysis notes that the age group between 25 and 55 has a statistically significant positive impact on the FOI-an indication that individuals aged within the established working career age group are more likely to adopt FinTech services. Of particular interest is the statistically significant negative impact on the FOI for the age group between 65 and 99-an indication that elderly individuals in the regions may not be as open to FinTech expansion when compared with the younger age groups. Also, there is a statistically significant positive impact of the age group $[55,65)$ on the FOI in both country groups, even though a statistically significant effect is not noted for fixed-effect analysis. We further find that having tertiary education or above has a statistically significant positive impact on the FOI for both SAARC and ASEAN countries. Additionally, having secondary education has a statistically significant positive impact for ASEAN countries. This is an indication that more highly educated individuals are more receptive to FinTech expansion in the regions. Also, individuals from ASEAN countries appear more likely to be FinTech adopters.

\section{Discussion}

Assessment of the GFD reveals some interesting insights that are particularly relevant to the expansion of FinTech services across markets, including those from the SAARC and ASEAN regions. First, it is notable that the opportunities for FinTech services in the two regions vary. With a higher percentage of participants already using a mobile phone or internet for payment, purchase, or cash transactions in countries such as Singapore, Malaysia, Thailand, Vietnam, Indonesia, and Bangladesh, it could be argued that FinTechs, and associated services hold potential opportunities in these countries, while the opportunity for development in other countries is less evident. Indeed, research suggests that users' trust that smartphones meet usage expectations, and their familiarity with smartphones, will positively influence the continued use of technology (Idemudia and Raisinghani 2014). A recent study noted that users' experience with mobile payments and transfers were significant factors that influenced their adoption of mobile investment technologies (Fan 2021). Thus, individuals not accustomed to digital technologies such as the internet or mobile phones for payment, purchase, or cash transactions may not be interested in adopting innovative services such as FinTechs. For these reasons, irrespective of the service provided, FinTechs companies may face obstacles in some ASEAN and especially SAARC countries. The FinTech services that are in use in SAARC countries mainly relate to mobile money and payment services. By contrast, in ASEAN countries such as Singapore, Malaysia, and Thailand, where there are supportive regulatory sandboxes and policies (Laik and Wei 2019), and where the GFD shows a notable interest in technology usage, a variety of FinTech services have grown and prospered in recent years.

The diversity of barriers faced in the different SAARC and ASEAN countries, particularly those related to having a bank account, is informative and provides the basis for further insights. In particular, having insufficient funds is a principal barrier across most regions, but especially in SAARC countries. This finding corroborates with the way FinTech expansion has occurred in the regions. As indicated earlier, in countries such as Afghanistan and Myanmar, costs associated with infrastructure and services have hindered FinTech adoptions (Aye 2021; Lukonga 2021). FinTechs can reduce operational, transaction, and intermediation costs (Miskam et al. 2019). Therefore, for FinTech services to develop in these regions, it is imperative that FinTechs consider and promote the cost benefits their services bring to consumers (Tapanainen 2020). As research points out, FinTech companies often collect customer data but it is unclear to what extent the data is used to achieve efficiencies and reduce costs as opposed to achieving profit (Tapanainen 2020). Arguably, opportunities for FinTech expansion in SAARC and ASEAN regions (where insufficient 
funds can be a principal barrier to having a bank account) will largely depend on market research and highlighting the cost advantages to end users.

Also, while some studies have emphasised the availability of special services such as Islamic FinTechs (e.g., Ahmad and Mamun 2020; Haqqi 2020; Miskam et al. 2019), religion of itself does not appear to be a notable barrier to having bank accounts in either region. Rather, analysis reveals there are more significant barriers to financial inclusion that FinTech services will need to address if they are hopeful of gaining further inroads into these two regions. In the ASEAN region, for example, missing documentation is seen as a significant barrier in enabling potential customers to open a bank account. To achieve feasible growth in the ASEAN region it is important for FinTech services such as RegTechs to develop more accessible and user-friendly authentication procedures, which would enable the less technology-savvy consumers to access FinTech services. Research already points to the need for innovative authentication processes in Brunei (Haqqi 2020). Thailand's central platform for verification of individual identity is viewed as supportive to the development of different FinTech services (Moenjak et al. 2020). It should also be noted that insufficient funds and user mistrust is noted as a considerable barrier to having a bank account in both the SAARC and ASEAN regions, and such mistrust is likely to hinder FinTech developments in the absence of a robust regulatory framework. Arguably, the expansion of FinTechs in both regions will depend on the extent of RegTech developments within the respective framework environment of each country.

One aspect this article focuses on, and which stands out compared to the focus in the extant literature, is the saving, borrowing, and payment-receipt behaviours of individuals in the regions. Overall, participants from the ASEAN regions appear to be higher savers and borrowers of money for business activities than those from SAARC regions. Business entrepreneurship and growth require funds. Crowdfunding and peer-to-peer lending can be viable sources for raising such funds (Nepali 2021; Yunus 2019). There is high growth potential for business-associated FinTechs such as crowdfunding, peer-to-peer lending, InsurTech, and RegTech in ASEAN regions. Conversely, each of these FinTech services face difficulties when expanding, especially in SAARC countries. We argue that supportive policies and regulation that encourage entrepreneurship and business financing would considerably improve the likelihood of FinTech development in these two regions.

Participants from ASEAN regions, on average, are higher savers of money for oldage security and are higher borrowers of money for purchasing assets than those from SAARC countries. This implies a positive attitude towards investments in the ASEAN region, which in turn corresponds to opportunities for FinTech development in the form of personal financial management, and WealthTechs.

Participants from SAARC regions, on average, however, appear to be higher borrowers of money for health purposes than those from ASEAN regions. Arguably, this reflects the diversity of health care systems in these regions. There is a push for a universal health care system in many ASEAN countries (Van Minh et al. 2015), and despite some inequalities, health care services cover much of the ASEAN population (Van Minh et al. 2015). Although there are some publically-funded health services, health care costs in many of the SAARC regions can be very high (Hassan et al. 2014). Thus, there lies opportunities for the development for FinTechs such as InsurTechs covering health insurance, as well as low-cost borrowing services such as LendTechs and neobanks in SAARC countries.

Research notes that mobile payments can be viewed by users as providing additional convenience compared to bank card payments (Dorotic and Pauwels 2020). Arguably, this implies that people are used to using bank cards, which can pave the way for advanced FinTechs linked to payment services. However, since most of the population in both the ASEAN and SAARC regions still prefer cash over bank cards when receiving different types of money, FinTech expansions in these regions face the challenge of attracting new consumers, especially within the population who remain outside the formal banking sector and who are not accustomed to using bank cards. Indeed, this challenge becomes evident from the noticeable gap in both regions between the percentage of participants using mobile 
phones and those having mobile money accounts. Marketing literature suggests that, in the modern era, educating customers about the process and benefits of using technological products will influence their usage decisions (Lewnes and Keller 2019). There is also a view that market penetration by a single technology product can be difficult in the modern era, and there is a need for collaboration and partnership (Lewnes and Keller 2019). Considering this, the expansion of FinTechs in the SAARC and ASEAN regions depends not only on providing cheaper services and bringing convenience or efficiency to the end users, but also on how providers collaboratively promote their service and educate end users to make best use of the technologies.

The regression analysis, along with the newly developed index revealed some interesting insights. A study involving Malaysian participants (Tun-Pin et al. 2019), concluded that males were the more likely adopters of FinTech services than were females. Our analysis of both the SAARC and ASEAN regions is consistent with the findings of Tun-Pin (Tun-Pin et al. 2019). Additionally, the elderly population beyond retirement age (i.e., those aged 65 and over) appear less likely to adopt or use FinTech services as compared to the younger-aged population. Thus, it seems that the elderly and women represent untapped markets. Research suggests that women in SAARC countries have low awareness of mobile money awareness (GSMA 2019). Another study, also involving the same data as this article (World Bank 2018a), points to the gender divide in financial inclusion in ASEAN countries, especially with women more likely than men to use cash for payments (Cheah et al. 2021). Research among elderly people suggests that they are less likely to adopt technologies if they feel stressed by such use and if their expectations are not met (Golant 2017). According to modern marketing literature, there is an argument to promote FinTech services to the least receptive cohorts in SAARC and ASEAN regions (Lewnes and Keller 2019), by highlighting their potential benefits. Indeed, the positive impact of secondary and tertiary education levels on FinTech opportunities corroborate the importance of education in promoting FinTech adoptions in the regions.

Overall, in SAARC and ASEAN regions, just promoting and branding FinTech services as alternatives to formal services may not achieve sufficient traction. There is a need to plan value propositions according to the savings, borrowing, and payment practices in the respective markets. An obstacle for SAARC initiatives in achieving the desired outcomes of integration of technology into financial services offerings, and hence economic development, has been the lack of an essential agreement between SAARC nations (Pandey et al. 2019). ASEAN countries, in contrast, demonstrate a moderate level of financial and banking integration (Fry-McKibbin et al. 2018; Zhang and Matthews 2019). This divergence might help explain regional variations between SAARC and ASEAN countries in terms of the opportunities and challenges of FinTech expansion, with ASEAN countries appearing more conducive in this respect.

\section{Conclusions}

This article explores the opportunities and barriers of FinTech developments in the SAARC and ASEAN regions. We use the GFD data collected in 2017 to conduct a comprehensive analysis of responses to the GFD questionnaire from various angles. Overall, it is noted that FinTech services hold potential opportunities for expansions in the ASEAN region, while expansion in the SAARC region is more problematic. There also lies different levels of opportunities for different categories of FinTechs in the regions. Services such as crowdfunding, neobanks, and InsurTech have sound growth potential in the ASEAN region, especially with the positive attitude towards entrepreneurship and asset investments. In the SAARC regions, InsurTechs linked to health care, LendTechs, and neobanks have growth potential. Additionally, we note the need for innovative promotions and the education of users about the benefits of technologies in both regions to motivate cohorts that are less likely to adopt FinTech services. We also develop an opportunity index that helps facilitate further insights into the opportunities and barriers to FinTech expansion. 
As with most studies, this research also has certain limitations. A limitation of this research relates to the fact that the GFD data was collected in 2017, and the results are dependent on participants that featured in the GFD. Although we assume that the context, despite some changes in recent years, has not shifted significantly, future research could explore FinTech in the regions further with recent information and potentially a larger participant base. Another limitation of the research is that we have assumed that the opportunities for FinTech may also translate into profitable developments in the region. Such may or may not be the case, depending on context. However, with a notable interest concerning FinTech in each region and a lack of research that explores this issue, the outcomes derived can still be of interest to relevant business leaders and policy makers and guide further research in the field. Lastly, as explained earlier in this article, the scores assigned in index development are subjective and the outcomes are to be considered with such subjectivity. Even so, as also reflected in the article, the index has both a rationale and statistical basis concerning its suitability. Future research will explore the index development further by including other data and considering other scoring approaches. Any future undertaking could also address another relevant issue, which could not be covered in this research due to lack of relevant data-how the index adapts when considering any change over time. Overall, despite some limitations, we are confident that we have contributed to the body of literature in this research domain with a unique analysis of FinTech opportunities and challenges in SAARC and ASEAN countries. The index and research findings should prove useful to different stakeholders and pioneer further relevant studies.

Author Contributions: Conceptualization, all authors; methodology, T.I.; software, T.I.; validation, all authors; formal analysis, T.I.; investigation, T.I. and A.M.; resources, T.I. and A.M.; data curation, T.I.; writing—original draft preparation, T.I. and A.M.; writing—review and editing, S.C. and R.G.; visualization, T.I.; supervision, T.I. and S.C.; project administration, T.I.; funding acquisition, all authors. All authors have read and agreed to the published version of the manuscript.

Funding: This research received no external funding.

Institutional Review Board Statement: Not applicable.

Informed Consent Statement: Not applicable.

Data Availability Statement: Data used in this research is available from the World Bank (World Bank 2018b).

Acknowledgments: The authors would like to acknowledge the support from the Accounting and Finance Association of Australia and New Zealand (AFAANZ).

Conflicts of Interest: The authors declare no conflict of interest.

\section{References}

Ab, Razak, Muhammad Ilyas Bin, Nur Akma Mohd Dali, Guru Dhillon, and Azwina Wati Manaf. 2020. Fintech in Malaysia: An Appraisal to the Need of Shariah-Compliant Regulation. Pertanika Journal of Social Science and Humanities 28: 3223-33. [CrossRef]

Abdillah, Leon A. 2020. FinTech E-Commerce Payment Application User Experience Analysis during COVID-19 Pandemic. Scientific Journal of Informatics 7: 265-78.

Abeyasekera, Savitri. 2005. Chapter XVIII Multivariate Methods for Index Construction. In Household Sample Surveys in Developing and Transition Countries. New York: United Nations, pp. 367-87.

Agarwal, Sumit, Wenlan Qian, Yuan Ren, Hsin-Tien Tsai, and Bernard Yin Yeung. 2020. The Real Impact of FinTech: Evidence from Mobile Payment Technology. SSRN Scholarly Paper ID 3556340. Rochester: Social Science Research Network. [CrossRef]

Agrawal, Ajay K., Christian Catalini, and Avi Goldfarb. 2011. The Geography of Crowdfunding. Working Paper 16820. Working Paper Series. Cambridge: National Bureau of Economic Research. [CrossRef]

Ahmad, Syed Magfur, and Abdullah Al Mamun. 2020. Opportunities of Islamic FinTech: The Case of Bangladesh and Turkey. CenRaPS Journal of Social Sciences 2: 412-26. [CrossRef]

Akhter, Sharmin. 2019. Comparative Analysis of FDI in SAARC and ASEAN Countries. IOSR Journal of Economics and Finance 10: 1-5.

Alam, Nafis, and Abdolhossein (Pejman) Zameni. 2021. Central Banks and Financial Authorities: Towards the Advancement of I-Fintech. In Islamic FinTech: Insights and Solutions. Edited by Mohd Ma'Sum Billah. Cham: Springer International Publishing, pp. 59-72. [CrossRef] 
Ali, Hassnian, Rose Abdullah, and Muhd Zaki Zaini. 2019. Fintech and Its Potential Impact on Islamic Banking and Finance Industry: A Case Study of Brunei Darussalam and Malaysia. International Journal of Islamic Economics and Finance (IJIEF) 2: 73-108. [CrossRef] Ali, Muhammad, Syed Ali Raza, Bilal Khamis, Chin Hong Puah, and Hanudin Amin. 2021. How Perceived Risk, Benefit and Trust Determine User Fintech Adoption: A New Dimension for Islamic Finance. Foresight 23: 403-20. [CrossRef]

Arner, Douglas W., Janos Barberis, and Ross P. Buckley. 2016. 150 Years of Fintech: An Evolutionary Analysis. JASSA 22-29. [CrossRef] Arslanian, Henri. 2018. How China Is Shaping WealthTech and the Future of Financial Services. In The WealthTech Book. New York: John Wiley \& Sons, Ltd., pp. 282-84. [CrossRef]

Association of South East Asian Nations. 2020. Home. Jakarta: ASEAN. Available online: https:/ /asean.org/ (accessed on 13 September 2021).

Aujirapongpan, Somnuk, Yaninee Songkajorn, Supit Ritkaew, and Sirichai Deelers. 2020. Japan's Digital Advance Policy towards Performance in Multilateral ASEAN's Innovation Business. Entrepreneurship and Sustainability Issues 8: 1081-94. [CrossRef]

Avirutha, Anupong Avirutha. 2021. ASEAN in Digital Economy: Opportunities and Challenges. Journal of ASEAN PLUS Studies 2: 17-25.

Aye, Thida. 2021. Adoption of Fintech and Policy Recommendations: The Case For Digital Lending Platform in Myanmar. Ph.D. thesis, National University of Singapore, Singapore.

Ayoungman, Fairtown Zhou, Nazmul Hasan Chowdhury, Nida Hussain, and Papel Tanchangya. 2021. User Attitude and Intentions Towards FinTech in Bangladesh. International Journal of Asian Business and Information Management (IJABIM) 12: 1-19. [CrossRef]

Babu, A. V. Ajay. 2016. A Comparative Analysis of Best Practices of Mobile Banking in ASEAN Countries and India. Area Studies 10: 21-38.

Banna, Hasanul, and Md Rabiul Alam. 2021. Impact of Digital Financial Inclusion on ASEAN Banking Stability: Implications for the Post-COVID-19 Era. Studies in Economics and Finance 38: 504-23. [CrossRef]

Bazarbash, Majid. 2020. Fintech in Nepal. In Nepal: Selected Issues. Washington, DC: International Monetary Fund. Asia and Pacific Department, pp. 23-25.

Blumenstock, Joshua E., Michael Callen, Tarek Ghani, and Lucas Koepke. 2015. Promises and Pitfalls of Mobile Money in Afghanistan: Evidence from a Randomized Control Trial. In Proceedings of the Seventh International Conference on Information and Communication Technologies and Development (ICTD'15), Singapore, May 15-18. New York: Association for Computing Machinery, pp. 1-10. [CrossRef]

Butler, Tom, and Leona O’Brien. 2019. Understanding RegTech for Digital Regulatory Compliance. In Disrupting Finance. Edited by Theo Lynn, John G. Mooney, Pierangelo Rosati and Mark Cummins. Cham: Palgrave Pivot, pp. 85-102.

Carlin, Bruce, Arna Olafsson, and Michaela Pagel. 2017. FinTech Adoption across Generations: Financial Fitness in the Information Age. Cambridge: National Bureau of Economic Research, p. w23798. [CrossRef]

Cheah, Wen Chong, Ammu George, and Taojun Xie. 2021. Gender Divides in the ASEAN Payment Eco-System. ACI Research Paper \#15-2021. Asia Competitiveness Institute Research Paper Series. Singapore: Asia Competitiveness Institute. [CrossRef]

Cheng, Fenchi Melissa, Khim Chamroeun, and Thai Sivmey. 2018. Consumer Adoption of E-Wallets: A Study of Millennials at the Institute of Foreign Languages, Cambodia. Paper presented at the 21st Asia-Pacific Conference on Global Business, Economics, Finance \& Social Sciences (AP18Taiwan Conference), Taipei, Taiwan, December 21-22; pp. 1-16. Available online: http://globalbizresearch.org/Taiwan_Conference_Dec_2018_2/docs/doc/2.\%20Global\%20Business, \%20Economics\%20 \&\%20Sustainability/W812_Abstract.pdf (accessed on 13 September 2021).

Chinnasamy, Gopalakrishnan, Araby Madbouly, and Sameh Reyad. 2021. Fintech: A Pathway for MENA Region. In The Fourth Industrial Revolution: Implementation of Artificial Intelligence for Growing Business Success. Edited by Allam Hamdan, Aboul Ella Hassanien, Anjum Razzaque and Bahaaeddin Alareeni. Basingstoke: Springer Nature, pp. 135-51.

Dahlberg, Tomi, Jie Guo, and Jan Ondrus. 2015. A Critical Review of Mobile Payment Research. Electronic Commerce Research and Applications 14: 265-84. [CrossRef]

Dahlberg, Tomi, Niina Mallat, Jan Ondrus, and Agnieszka Zmijewska. 2008. Past, Present and Future of Mobile Payments Research: A Literature Review. Electronic Commerce Research and Applications 7: 165-81. [CrossRef]

Dang, Thuy T., and Huong Quynh Vu. 2020. Fintech in Microfinance: A New Direction for Microfinance Institutions in Vietnam. Asian Journal of Business Environment 10: 13-22. [CrossRef]

Darma, Dio Caisar, Muhammad Kadafi, and Dirga Lestari. 2020. FinTech and MSMEs Continuity: Applied in Indonesia. International Journals 29: 4676-85.

Davis, Fred D. 1993. User Acceptance of Information Technology: System Characteristics, User Perceptions and Behavioral Impacts. International Journal of Man-Machine Studies 38: 475-87. [CrossRef]

Davis, Fred D., Richard P. Bagozzi, and Paul R. Warshaw. 1989. User Acceptance of Computer Technology: A Comparison of Two Theoretical Models. Management Science 35: 982-1003. [CrossRef]

de Luna, Iviane Ramos, Francisco Liébana-Cabanillas, Juan Sánchez-Fernández, and Francisco Muñoz-Leiva. 2019. Mobile Payment Is Not All the Same: The Adoption of Mobile Payment Systems Depending on the Technology Applied. Technological Forecasting and Social Change 146: 931-44. [CrossRef]

Demirguc-Kunt, Asli, and Leora Klapper. 2012. Measuring Financial Inclusion: The Global Findex Database. Policy Research Working Papers. Washington, DC: The World Bank. [CrossRef]

Demirguc-Kunt, Asli, Leora Klapper, Dorothe Singer, Saniya Ansar, and Jake Hess. 2018. The Global Findex Database 2017: Measuring Financial Inclusion and the Fintech Revolution. Washington, DC: World Bank Group. 
Dey, Bidit Lal, Meera Sarma, Ameet Pandit, David Sarpong, Sushma Kumari, and Khanyapuss Punjaisri. 2019. Social Media Led Co-Creation of Knowledge in Developing Societies: SME's Roles in the Adoption, Use and Appropriation of Smartphones in South Asia. Production Planning \& Control 30: 1019-31. [CrossRef]

Dhar, Vasant, and Roger M. Stein. 2017. Economic and Business Dimensions FinTech Platforms and Strategy. Communications of the ACM 60: 32-35. [CrossRef]

Dharmadasa, P. D. C. S. 2021. "Fintech Services" and the Future of Financial Intermediation: A Review. Sri Lanka Journal of Economic Research 8: 21-38. [CrossRef]

Dorotic, Matilda, and Koen Pauwels. 2020. What's in Your Mobile Wallet? Purchase Effects of Downloading versus Adopting Mobile Payment Instruments. Marketing Science Institute Working Paper Series; New York: MSI. Available online: https://www.msi.org/wpcontent/uploads/2020/12/MSI_Report_20-140.pdf (accessed on 13 September 2021).

Dubey, Vivek, Rakesh Sonar, and Anindya Mohanty. 2020. FinTech, RegTech and Contactless Payments through the Lens of COVID 19 Time. International Journal of Advanced Science and Technology 29: 3727-34.

Dziawgo, Tomasz. 2021. Wealth Tech Impact on Wealth Management Sector. European Research Studies Journal XXIV: 141-51. [CrossRef]

El-Gohary, Hatem, Aksaya Thayaseelan, Simeon Babatunde, and Salma El-Gohary. 2021. An Exploratory Study on the Effect of Artificial Intelligence-Enabled Technology on Customer Experiences in the Banking Sector. Journal of Technological Advancements 1: 1-17. [CrossRef]

Fan, Lu. 2021. Mobile Investment Technology Adoption among Investors. International Journal of Bank Marketing 40: 50-67. [CrossRef]

Fan, Pei Sai. 2018. Chapter 15-Singapore Approach to Develop and Regulate FinTech. In Handbook of Blockchain, Digital Finance, and Inclusion. Edited by David Lee Kuo Chuen and Robert Deng. New York: Academic Press, vol. 1, pp. 347-57. [CrossRef]

FIS of Royal Monetary Authority of Bhutan. 2020. The Kingdom of Bhutan's Financial Inclusion Journey. Kuala Lumpur: Alliance for Financial Inclusion. Available online: https://www.afi-global.org/sites/default/files/publications/2020-12/AFI_Bhutan_MS_ AW_digital.pdf (accessed on 9 October 2021).

Fry-McKibbin, Renée, Cody Yu-Ling Hsiao, and Vance L. Martin. 2018. Global and Regional Financial Integration in East Asia and the ASEAN. The North American Journal of Economics and Finance 46: 202-21. [CrossRef]

Golant, Stephen M. 2017. A Theoretical Model to Explain the Smart Technology Adoption Behaviors of Elder Consumers (Elderadopt). Journal of Aging Studies 42: 56-73. [CrossRef]

Gomber, Peter, Jascha-Alexander Koch, and Michael Siering. 2017. Digital Finance and FinTech: Current Research and Future Research Directions. Journal of Business Economics 87: 537-80. [CrossRef]

Government of India, Ministry of Electronics \& Information Technology. n.d. Digital India Programme (Vision and Vision Areas). Available online: https:/ / digitalindia.gov.in/content/vision-and-vision-areas\#collapseone--19 (accessed on 9 October 2021).

GSMA. 2019. State of the Industry Report on Mobile Money. Available online: https://www.gsma.com/sotir/wp-content/uploads/20 20/03/GSMA-State-of-the-Industry-Report-on-Mobile-Money-2019-Full-Report.pdf (accessed on 13 September 2021).

Gupta, Agrata, and Chun Xia. 2018. A Paradigm Shift in Banking: Unfolding Asia's FinTech Adventures. In Banking and Finance Issues in Emerging Markets. Bingley: Emerald Publishing Limited, vol. 25, pp. 215-54. [CrossRef]

Haqqi, Abdurrahman. 2020. Strengthening Islamic Finance in South-East Asia through Innovation of Islamic FinTech in Brunei Darussalam. Hershey: IGI Global, pp. 202-26. [CrossRef]

Hasan, Rashedul. 2021. Factors Affecting Adoption of Fintech in Bangladesh. International Journal of Science and Business 5: 156-64.

Hasan, Rashedul, Mohammad Kabir Hassan, and Sirajo Aliyu. 2020. Fintech and Islamic Finance: Literature Review and Research Agenda. International Journal of Islamic Economics and Finance (IJIEF) 3: 75-94. [CrossRef]

Hassan, Syeda Anam, Khalid Zaman, Sajid Zaman, and Muhammad Shabir. 2014. Measuring Health Expenditures and Outcomes in Saarc Region: Health Is a Luxury? Quality $\mathcal{E}$ Quantity 48: 1421-37. [CrossRef]

Hiller, James. 2016. Epistemological Foundations of Objectivist and Interpretivist Research. In Music Therapy Research, 3rd ed. Dallas: Barcelona Publishers, pp. 99-127.

Hornuf, Lars, and Armin Schwienbacher. 2018. Market Mechanisms and Funding Dynamics in Equity Crowdfunding. Journal of Corporate Finance 50: 556-74. [CrossRef]

Huong, Alice, Chin-Hong Puah, and Mei-Teing Chong. 2021. Embrace Fintech in ASEAN: A Perception through Fintech Adoption Index. Research in World Economy 12: 1. [CrossRef]

Huwaydi, Yasir, and Satria Fadil Persada. 2018. Descriptive analysis of go-pay users in surabaya. Jurnal Teknik ITS 7. [CrossRef]

Idemudia, Efosa, and Mahesh Raisinghani. 2014. The Influence of Cognitive Trust and Familiarity on Adoption and Continued Use of Smartphones: An Empirical Analysis. Journal of International Technology and Information Management 23: 6.

Iman, Nofie. 2018. Is Mobile Payment Still Relevant in the Fintech Era? Electronic Commerce Research and Applications 30: 72-82. [CrossRef]

Jagtiani, Julapa, Lauren Lambie-Hanson, and Timothy Lambie-Hanson. 2021. Fintech Lending and Mortgage Credit Access. The Journal of FinTech 1: 2050004. [CrossRef]

Jagtiani, Julapa, and Catharine Lemieux. 2019. The Roles of Alternative Data and Machine Learning in Fintech Lending: Evidence from the LendingClub Consumer Platform. Financial Management 48: 1009-29. [CrossRef]

Jain, Sudeep, and Daniela Gabor. 2020. The Rise of Digital Financialisation: The Case of India. New Political Economy 25: 813-28. [CrossRef] 
Kang, Jungho. 2018. Mobile Payment in Fintech Environment: Trends, Security Challenges, and Services. Human-Centric Computing and Information Sciences 8: 32. [CrossRef]

Kharisma, Dona Budi. 2020. Urgency of Financial Technology (Fintech) Laws in Indonesia. International Journal of Law and Management 63: 320-31. [CrossRef]

Kourlaba, Georgia, and Demosthenes B. Panagiotakos. 2009. Dietary Quality Indices and Human Health: A Review. Maturitas 62: 1-8. [CrossRef] [PubMed]

Kumar, N. Subrahmanya, and K. Puttanna. 2018. Payments Transition in India-Consumer Preferences and Policy Shifts. Banks and Bank Systems 13: 17-30. [CrossRef]

Kunwar, Bhabuk Singh, and R. N. Thakur. 2019. User Acceptance of Mobile Banking: A Demographic Study of Nepal Focusing on Young Customer Aged (25-40). LBEF Research Journal of Science, Technology and Management 1: 22-40.

Laik, Dr Ma Nang, and Chester Mark Hong Wei. 2019. Creating a Unique Mobile Financial Services Framework for Myanmar: A Review. arXiv arXiv:1910.03793.

Lenka, Sanjaya Kumar, and Rajesh Barik. 2018. Has Expansion of Mobile Phone and Internet Use Spurred Financial Inclusion in the SAARC Countries? Financial Innovation 4: 1-19. [CrossRef]

Lewnes, Ann, and Kevin Lane Keller. 2019. 10 Principles of Modern Marketing. MIT Sloan Management Review 60: 1-10.

Li, Tao, Hongchao Zhang, Chris Yuan, Zhichao Liu, and Chengcheng Fan. 2012. A PCA-Based Method for Construction of Composite Sustainability Indicators. The International Journal of Life Cycle Assessment 17: 593-603. [CrossRef]

Li, Xiaoyang, Haitian Lu, and Iftekhar Hasan. 2020. The Promises and Pitfalls of WealthTech: Evidence from Online Marketplace Lending. Available online: https://papers.ssrn.com/sol3/papers.cfm?abstract_id=3575260 (accessed on 21 October 2020). [CrossRef]

Lin, Lin. 2019. Regulating FinTech: The Case of Singapore. SSRN Electronic Journal 35: 94-119. [CrossRef]

Low, ChiaSean, and MeiFoong Wong. 2021. The Effect of FinTech on the Financial Institution in Six ASEAN Countries: Fama-French Five-Factor Asset Pricing Model Approach. Paris: Atlantis Press, pp. 224-32. [CrossRef]

Lukonga, Inutu. 2021. Fintech and the Real Economy: Lessons from the Middle East, North Africa, Afghanistan, and Pakistan (MENAP) Region. In The Palgrave Handbook of FinTech and Blockchain. Edited by Maurizio Pompella and Roman Matousek. Cham: Springer International Publishing, pp. 187-214. [CrossRef]

Luther, William J. 2016. Bitcoin and the Future of Digital Payments. The Independent Review 20: 397-440. [CrossRef]

Maiti, Moinak, Darko Vuković, Amrit Mukherjee, Pavan D. Paikarao, and Janardan Krishna Yadav. 2021. Advanced Data Integration in Banking, Financial, and Insurance Software in the Age of COVID-19. Software: Practice and Experience. [CrossRef]

Mardiana, Harisa, and Esther Kembauw. 2021. The Role of Diffusion of Innovation in Agricultural to Compete in Asean Community. IOP Conference Series: Earth and Environmental Science 755: 012074. [CrossRef]

Meyliana, Meyliana, Erick Fernando, and Surjandy Surjandy. 2019. The Influence of Perceived Risk and Trust in Adoption of FinTech Services in Indonesia. CommIT (Communication and Information Technology) Journal 13: 31-37. [CrossRef]

Meyskens, Moriah, and Lacy Bird. 2015. Crowdfunding and Value Creation. Entrepreneurship Research Journal 5: 155-66. [CrossRef]

Miskam, Surianom, Abdul Monir Yaacob, and Romzie Rosman. 2019. Fintech and Its Impact on Islamic Fund Management in Malaysia: A Legal Viewpoint. In Emerging Issues in Islamic Finance Law and Practice in Malaysia. Edited by Umar A. Oseni, M. Kabir Hassan and Rusni Hassan. Bingley: Emerald Publishing Limited, pp. 223-46. [CrossRef]

Moenjak, Thammarak, Anyarat Kongprajya, and Chompoonoot Monchaitrakul. 2020. FinTech, Financial Literacy, and Consumer Saving and Borrowing: The Case of Thailand. Tokyo: Asian Development Bank Institute. Available online: https://www.adb.org/sites/ default/files/publication/575576/adbi-wp1100.pdf (accessed on 20 September 2021).

Mohammad, K. Al Nawayseh. 2020. FinTech in COVID-19 and Beyond: What Factors Are Affecting Customers' Choice of FinTech Applications? Journal of Open Innovation 6: 153. [CrossRef]

Mollick, Ethan. 2014. The Dynamics of Crowdfunding: An Exploratory Study. Journal of Business Venturing 29: 1-16. [CrossRef]

Moradi, Shiva, Nader Naderi, and Sohrab Delangizan. 2020. Analyzing Fintech Startups Development Process in Iran. Journal of Entrepreneurship Development 13: 121-40. [CrossRef]

Morgan, Peter J., and Trinh Q. Long. 2019. Fintech and Financial Literacy in the Lao PDR (Lao People's Democratic Republic). Tokyo: Asian Development Bank Institute. Available online: https://www.adb.org/publications/fintech-and-financial-literacy-lao-pdr (accessed on 20 September 2021).

Morgan, Peter J., and Long Q. Trinh. 2020. Fintech and Financial Literacy in Vietnam. Tokyo: Asian Development Bank Institute. Available online: https:/ / www.adb.org/sites/default/files/publication/616781/adbi-wp1154.pdf (accessed on 20 October 2021).

Neale, Faith Roberts, Pamela Peterson Drake, and Theodoros Konstantopoulos. 2020. InsurTech and the Disruption of the Insurance Industry. Journal of Insurance Issues 43: 64-96.

Nepali, Som Raj. 2021. Crowdfunding Prospects in Nepal. Global Journal of Management and Business Research. [CrossRef]

Ng, Reuben. 2018. Cloud Computing in Singapore: Key Drivers and Recommendations for a Smart Nation. Politics and Governance 6: 39-47. [CrossRef]

Noonpakdee, Wasinee. 2020. The Adoption of Artificial Intelligence for Financial Investment Service. Paper presented at 2020 22nd International Conference on Advanced Communication Technology (ICACT), PyeongChang, Korea, February 16-19; pp. 396-400. [CrossRef] 
OECD. 2020. Digital Disruption in Banking and Its Impact on Competition. Available online: http://www.oecd.org/daf/competition/ digital-disruption-in-financial-markets.htm (accessed on 13 October 2021).

OECD. 2021. Employment Rate by Age Group (Indicator). Available online: http://data.oecd.org/emp/employment-rate-by-agegroup.htm (accessed on 25 November 2021).

Pandey, Piyush, Sanjay Sehgal, and Wasim Ahmad. 2019. Dynamics of Banking Sector Integration in South Asia: An Empirical Study. Indian Growth and Development Review 12: 315-32. [CrossRef]

Patil, Pushp, Yogesh Dwivedi, and Nripendra Rana. 2017. Digital Payments Adoption: An Analysis of Literature. ILNCS-10595. Cham: Springer International Publishing, p. 61. [CrossRef]

Patil, Pushp P., Nripendra P. Rana, and Yogesh K. Dwivedi. 2018. Digital Payments Adoption Research: A Review of Factors Influencing Consumer's Attitude, Intention and Usage. In Challenges and Opportunities in the Digital Era I3E 2018. Edited by Salah A. Al-Sharhan, Antonis C. Simintiras, Yogesh K. Dwivedi, Marijn Janssen, Matti Mäntymäki, Luay Tahat, Issam Moughrabi, Taher M. Ali and Nripendra P. Rana. Cham: Springer International Publishing, vol. 11195, pp. 45-52.

Pollari, Ian, and Daniel Teper. 2021. Australian Fintech Landscape 2020-KPMG Australia. Amsterdam: KPMG. Available online: https:/ /home.kpmg/au/en/home/insights/2017/08/australian-fintech-landscape.html (accessed on 17 November 2021).

Prasad, Smitha Krishna, and Sharngan Aravindakshan. 2021. Playing Catch up-Privacy Regimes in South Asia. The International Journal of Human Rights 25: 79-116. [CrossRef]

Priya, P. Krishna, and Anusha Kanagala. 2019. Fintech Issues and Challenges in India. International Journal of Recent Technology and Engineering 8: 2277-3878. [CrossRef]

Puschmann, Thomas. 2017. Fintech. Business \& Information Systems Engineering 59: 69-76. [CrossRef]

Ragimun, and Sri Yanthy Yosepha. 2018. The Role of Fintech Encourages the Export of Small Medium Enterprises in Indonesia. Journal of Social and Development Sciences 9: 66-77. [CrossRef]

Rahman, Benazir, Oeshwik Ahmed, and Shireen Shakil. 2021. Fintech in Bangladesh: Ecosystem, Opportunities and Challenges. International Journal of Business and Technopreneurship 11: 73-90.

Rahman, Mohammad Mafizur, Rasheda Khanam, and Maisha Rahman. 2018. Health Care Expenditure and Health Outcome Nexus: New Evidence from the SAARC-ASEAN Region. Globalization and Health 14: 113. [CrossRef]

Ralcheva, Aleksandrina, and Peter Roosenboom. 2016. On the Road to Success in Equity Crowdfunding. SSRN Scholarly Paper ID 2727742. Rochester: Social Science Research Network. [CrossRef]

Ryu, Hyun-Sun. 2018. Understanding Benefit and Risk Framework of Fintech Adoption: Comparison of Early Adopters and Late Adopters. Available online: https:/ / scholarspace.manoa.hawaii.edu/handle/10125/50374 (accessed on 3 January 2018).

Saleem, Asima. 2021. Fintech Revolution, Perceived Risks and Fintech Adoption: Evidence from Financial Industry of Pakistan. International Journal of Multidisciplinary and Current Educational Research 3: 191-205.

Samarasinghe, Thisan. 2021. COVID-19 Outbreak and FinTech Sector in Sri Lanka: Importance of Digital Transformation to Thrive. Global Scientific Journals 9: 884-95.

Schatt, Dan. 2014. Electronic Payments, Mobile Commerce, and Virtual Banking: A Guide to Innovation and Partnering. Oxford: Wiley-Blackwell.

Schellhase, John, and Amos Garcia. 2019. FinTech in the Philippines: Assessing the State of Play. Santa Monica: Milken Institute.

Schierz, Paul Gerhardt, Oliver Schilke, and Bernd W. Wirtz. 2010. Understanding Consumer Acceptance of Mobile Payment Services: An Empirical Analysis. Electronic Commerce Research and Applications 9: 209-16. [CrossRef]

Singh, Shubhangi, Marshal M. Sahni, and Raj K. Kovid. 2020. What Drives FinTech Adoption? A Multi-Method Evaluation Using an Adapted Technology Acceptance Model. Management Decision 58: 1675-97. [CrossRef]

South Asian Association for Regional Cooperation. 2020. About SAARC. Available online: https://www.saarc-sec.org/index.php/ about-saarc/about-saarc (accessed on 13 September 2021).

Srivastava, Chetan, Mahendar Goli, and Vishnu V. Ana. 2021. Adoption of Contactless Payments during Covid 19 Pandemic An Integration of Protection Motivation Theory (PMT) and Unified Theory of Acceptance and Use of Technology (UTAUT). Academy of Marketing Studies Journal 25: 1-20. Available online: https://www.abacademies.org/abstract/adoption-of-contactlesspayments-during-covid-19-pandemic-an-integration-of-protection-motivation-theory-pmt-and-unified-9970.html (accessed on 25 November 2021).

Stoeckli, Emanuel, Christian Dremel, and Falk Uebernickel. 2018. Exploring Characteristics and Transformational Capabilities of InsurTech Innovations to Understand Insurance Value Creation in a Digital World. Electronic Markets 28: 287-305. [CrossRef]

Sulaiman, Siti Nurdiyana Atikah, and Mohammad Nabil Almunawar. 2021. The Adoption of Biometric Point-of-Sale Terminal for Payments. Journal of Science and Technology Policy Management. [CrossRef]

Taber, Keith S. 2018. The Use of Cronbach's Alpha When Developing and Reporting Research Instruments in Science Education. Research in Science Education 48: 1273-96. [CrossRef]

Tao, Jaqueline, and Dina Azhgaliyeva. 2018. The Role of Green Fintech for Singapore: Risks and Benefits. ESI Bulletin 11: 8-10.

Tapanainen, Tommi. 2020. Toward Fintech Adoption Framework for Developing Countries-A Literature Review Based on the Stakeholder Perspective. Journal of Information Technology Applications and Management 27: 1-22. [CrossRef]

Temelkov, Zoran. 2020. Differences between Traditional Bank Model and Fintech Based Digital Bank and Neobanks Models. SocioBrains, International Scientific Refereed Online Journal with Impact Factor 74: 8-15.

Tun-Pin, Chong, William Choo Keng-Soon, Yip Yen-San, Chan Pui-Yee, Julian Teh Hong-Leong, and Ng Shwu-Shing. 2019. An Adoption of Fintech Service in Malaysia. South East Asia Journal of Contemporary Business, Economics and Law 18: 134-47. 
Ullah, A. K. M. Ahsan, and Hannah Ming Yit Ho. 2021. Globalisation and Cultures in Southeast Asia: Demise, Fragmentation, Transformation. Global Society 35: 191-206. [CrossRef]

Van Minh, Hoang, Nicola Suyin Pocock, Nathorn Chaiyakunapruk, Chhea Chhorvann, Ha Anh Duc, Piya Hanvoravongchai, Jeremy Lim, Don Eliseo Lucero-Prisno III, Nawi Ng, Natalie Phaholyothin, and et al. 2015. Progress toward Universal Health Coverage in ASEAN. Global Health Action 8: 25856. [CrossRef] [PubMed]

Vidyashree, S. 2021. Bhutan Becomes First Country to Adopt India's Unified Payment Interface (UPI). RepublicWorld. July 14. Available online: https:/ / www.republicworld.com/world-news/rest-of-the-world-news/bhutan-becomes-first-country-toadopt-indias-unified-payment-interface-upi-fin-min.html (accessed on 17 November 2021).

Widyastuti, Nurprapti Wahyu. 2017. Embedded Social Media and Its Implications for the Readiness of Sme's in Asean Economic Community Free Trade. Paper presented at the 1st International Conference on Social Sciences (ICSS), Jakarta, Indonesia, November 1-2.

World Bank. 2018a. The Global Findex Database 2017. Washington, DC: World Bank. Available online: https:/ /globalfindex.worldbank. org/ (accessed on 13 September 2021).

World Bank. 2018b. World-Global Financial Inclusion (Global Findex) Database 2017. Washington, DC: Development Research Group, Finance and Private Sector Development Unit-World Bank. Available online: https:/ / microdata.worldbank.org/index.php/ catalog/3324/data-dictionary (accessed on 13 September 2021).

Yang, Yongqing, Yong Liu, Hongxiu Li, and Benhai Yu. 2015. Understanding Perceived Risks in Mobile Payment Acceptance. Industrial Management E Data Systems 115: 253-69. [CrossRef]

Yunus, Ulani. 2019. A Comparison Peer to Peer Lending Platforms in Singapore and Indonesia. Journal of Physics: Conference Series 1235: 012008. [CrossRef]

Zahir, Mihna, and Behrooz Gharleghi. 2014. Adoption of Internet Banking in Maldives, the Most Important Determinants. Asian Social Science 11: 181. [CrossRef]

Zhang, Tiantian, and Kent Matthews. 2019. Assessing the Degree of Financial Integration in ASEAN-A Perspective of Banking Competitiveness. Research in International Business and Finance 47: 487-500. [CrossRef]

Zhang, Xun, Ying Tan, Zonghui Hu, Chen Wang, and Guanghua Wan. 2020. The Trickle-down Effect of Fintech Development: From the Perspective of Urbanization. China \& World Economy 28: 23-40. [CrossRef]

Zia, Uzma, and Zafar Mahmood. 2019. Tests of Income Convergence in ASEAN and SAARC Trading Blocs. South Asia Economic Journal 20: 167-83. [CrossRef] 